\title{
Production of multiple bacteriocins, including the novel bacteriocin gassericin M, by Lactobacillus gasseri LM19, a strain isolated from human milk
}

\author{
Enriqueta Garcia-Gutierrez ${ }^{1,2}$ (D) Paula M. O'Connor ${ }^{2,3}$ (D) $\cdot$ lan J. Colquhoun ${ }^{1} \cdot$ Natalia M. Vior $^{4}$ (D) \\ Juan Miguel Rodríguez ${ }^{5} \cdot$ Melinda J. Mayer $^{1}$ (D) Paul D. Cotter ${ }^{2,3}$ (D) Arjan Narbad $^{1}$
}

Received: 12 November 2019/Revised: 17 February 2020 / Accepted: 20 February 2020 /Published online: 13 March 2020

(C) The Author(s) 2020

\begin{abstract}
Bacteriocins are antimicrobial peptides produced by bacteria, and their production is regarded as a desirable probiotic trait. We found that Lactobacillus gasseri LM19, a strain isolated from human milk, produces several bacteriocins, including a novel bacteriocin, gassericin $\mathrm{M}$. These bacteriocins were purified from culture and synthesised to investigate their activity and potential synergy. L. gasseri LM19 was tested in a complex environment mimicking human colon conditions; it not only survived, but expressed the seven bacteriocin genes and produced short-chain fatty acids. Metagenomic analysis of these in vitro colon cultures showed that co-inoculation of L. gasseri LM19 with Clostridium perfringens gave 16S ribosomal RNA metagenomic profiles with more similarity to controls than to vessels inoculated with $C$. perfringens alone. These results indicate that L. gasseri LM19 could be an interesting candidate for maintaining homeostasis in the gut environment.
\end{abstract}

Keywords Bacteriocin · Antimicrobial · SCFA · Gassericin · Colon model $\cdot$ Lactobacillus gasseri

\section{Introduction}

Beneficial bacteria have consistently been harnessed throughout human history. Most recently, the rise of antimicrobial resistance among pathogens, a greater demand for healthy foods and an increasing appreciation of the importance of the human gut microbiota have brought attention back to natural sources of new antimicrobials, food preservatives and

Electronic supplementary material The online version of this article (https://doi.org/10.1007/s00253-020-10493-3) contains supplementary material, which is available to authorized users.

Paul D. Cotter

paul.cotter@teagasc.ie

1 Gut Microbes and Health Institute Strategic Programme, Quadram Institute Bioscience, Norwich, UK

2 Food Bioscience Department Teagasc Food Research Centre, Moorepark, Fermoy, Cork, Ireland

3 APC Microbiome Ireland, University College Cork, Cork, Ireland

4 Molecular Microbiology, John Innes Centre, Norwich, UK

5 Dpt. Nutrition and Food Science, Complutense University of Madrid, Madrid, Spain probiotics. The search for natural antimicrobials can involve a variety of approaches (Lewis 2013), including taking advantage of the fact that bacteria from a specific environmental niche are able to compete against other bacteria from the same niche (Czárán et al. 2002; Kelsic et al. 2015). Such bacterial antagonism can be through non-specific strategies, like the production of organic acids. Some organic acids, particularly the short-chain fatty acids (SCFA), acetate, propionate and butyrate, are produced in millimolar quantities in the gastrointestinal (GI) tracts of animals and humans and, in addition to their antagonistic activities, confer other health benefits (LeBlanc et al. 2017; Singh et al. 2018). Target-specific antagonistic activities can be provided by compounds such as bacteriocins (Garcia-Gutierrez et al. 2018), a heterogeneous group of ribosomally synthesised peptides. They represent a potential alternative to traditional antibiotics because of their frequent low toxicity, high potency, ability to be bioengineered, low likelihood of resistance development and the possibility of being produced in situ by probiotics (Cotter et al. 2013; Field et al. 2015; Hegarty et al. 2016).

Lactobacillus spp. are members of the lactic acid bacteria (LAB) and contribute to the production of many fermented foods, as well as being important components of the human gut microbiota and sources of antimicrobial peptides (Collins 
et al. 2017). Lactobacillus gasseri is one of six species which previously comprised the Lactobacillus acidophilus complex (Fujisawa et al. 1992; Sarmiento-Rubiano et al. 2010). These species are considered ecologically and commercially important and have been extensively studied, frequently revealing antimicrobial and other probiotic properties (Abramov et al. 2014; Karska-Wysocki et al. 2010; Kim et al. 2007; Selle and Klaenhammer 2013; Yamano et al. 2007). L. gasseri strains have been isolated from the gut of animals and humans, vaginal tract, human milk and oral cavity and have been found to produce different classes of bacteriocins, frequently referred to as gassericins. Gassericin A is a cyclic class IIc bacteriocin produced by L. gasseri LA39, from an infant faecal sample (Kawai et al. 1994; Pandey et al. 2013). Gassericins B1, B2, $\mathrm{B} 3$ and $\mathrm{B} 4$ were isolated from vaginal isolate $L$. gasseri JCM 2124 , with B1 and B3 being identical to the $\alpha$ and $\beta$ peptides of the two-component bacteriocin acidocin J1132 from L. acidophilus (Tahara et al. 1997). Production of gassericin T (GasT) was first reported in L. gasseri SBT 2055, a strain isolated from adult human faeces (Kawai et al. 2000). Although bacteriocins of class IIb have previously been shown to have one active peptide and one inactive complementary factor, the second peptide from the same cluster, GatX, was also shown to have antimicrobial activity (Mavrič et al. 2014). Acidocins LF221A and LF221B were isolated from L. acidophilus LF221 (later renamed L. gasseri LF221), from infant faeces (Bogovic-Matijasic et al. 1998). L. gasseri K7 was also isolated from the faeces of a breast-fed baby and two two-peptide bacteriocin-encoding operons were found in its genome (Zorič Peternel et al. 2010). These potential peptides showed high homology to acidocins LF221A and LF221B and gassericin T peptides, respectively (Mavric et al. 2014). The gassericin $E$ operon was identified in L. gasseri EV1461, isolated from the vagina of a healthy woman; it encodes both antimicrobial gassericin E, with high similarity to gassericin $\mathrm{T}$, and gene gaeX, whose product is identical to GatX and gassericin K7 B (Maldonado-Barragán et al. 2016). Recently, genes encoding gassericin T (GatA and GatX) and the novel gassericin $\mathrm{S}$, with similarity to acidocin LF221A (GasA and GasX), were found in the genome of L. gasseri LA327, isolated from the colon of a human adult (Kasuga et al. 2019). This study demonstrated synergistic activity between the two components of gassericin T, and those of gassericin $\mathrm{S}$, but not between gassericin $\mathrm{S}$ and gassericin $\mathrm{T}$ (Kasuga et al. 2019).

In this study, we aimed to characterise the antimicrobial and probiotic potential of a novel strain, L. gasseri LM19, isolated from human milk. We found that L. gasseri LM19 exhibits antimicrobial activity against different enteropathogens and possesses three bacteriocin clusters in its genome, including one encoding a novel bacteriocin, designated gassericin M. We examined antimicrobial activity and synergy using both purified and synthesised peptides. In order to examine potential probiotic use, we also demonstrated that L. gasseri LM19 survives, expresses all the bacteriocin genes, and produces SCFA in detectable amounts in a complex faecal environment mimicking colon conditions. In addition, it can help to maintain the composition of the microbiome in the presence of the pathogen Clostridium perfringens.

\section{Methods}

\section{Isolation and whole genome sequencing of $L$. gasseri LM19}

L. gasseri LM19 was originally isolated from breast milk on MRS agar (Oxoid España SA, Madrid, Spain) at $37^{\circ} \mathrm{C}$ and has been deposited in the National Collection of Industrial, Food and Marine Bacteria (NCIMB, Aberdeen, UK) with the accession number NCIMB 15251. Whole genome sequence was provided by MicrobesNG (Birmingham, UK) using Illumina ${ }^{\circledR}$ HiSeq and a 250 bp paired end protocol. Genome coverage was $\times 30$. Reads were trimmed using Trimmomatic 0.30 with a sliding window quality cutoff of Q15 (Bolger et al. 2014), and the quality was assessed using software Samtools ( $\mathrm{Li}$ et al. 2009), BedTools (Quinlan and Hall 2010), and BWA mem (Li and Durbin 2010). SPAdes 3.7 (Bankevich et al. 2012) was used for de novo assembly, and annotation was performed using Prokka 1.11 (Seemann 2014).

\section{Bioassay-based screening for antimicrobial activity}

Antimicrobial overlay assays, cross streaks, drop tests, filter disc tests and well diffusion assays were performed as described previously (Garcia-Gutierrez 2019), supplementing plates with $2 \% \mathrm{w} / v \mathrm{NaHCO}_{3}$ to counteract inhibition from lactic acid. Well diffusion assays incorporated $100 \mu \mathrm{l}$ of an overnight culture of the incubator strains. Bacterial strains used were from culture collections (ATCC, American Type Culture Collection, Manassas, Virginia, USA; DSMZ, Deutsche Sammlung von Mikroorganismen und Zellkulturen, Braunschweig, Germany; NCTC, National Collection of Type Cultures, London, UK) or in-house collections. Strains and culture conditions were: L. gasseri LM19 (MRS, $37^{\circ} \mathrm{C}$, anaerobic, static), Salmonella enterica LT2 (LB, $37^{\circ} \mathrm{C}$, anaerobic, static), Escherichia coli ATCC 25922 (LB, $37^{\circ} \mathrm{C}$, anaerobic, static), Cronobacter sakazakii DSMZ 4485 (BHI, $37^{\circ} \mathrm{C}$, anaerobic, static), C. perfringens NCTC 3110 (BHI, $37^{\circ} \mathrm{C}$, anaerobic, static), Listeria innocua $\mathrm{NCTC}$ 11288 (BHI, $37{ }^{\circ} \mathrm{C}$, anaerobic, static), Lactobacillus delbrueckii subsp. bulgaricus (L. bulgaricus) 5583 (MRS, $37{ }^{\circ} \mathrm{C}$, anaerobic, static), L. bulgaricus LMG 6901 (MRS, $37{ }^{\circ} \mathrm{C}$, aerobic, static), Campylobacter jejuni NCTC 11168 (Brucella medium, $37{ }^{\circ} \mathrm{C}$, microaerobic, static), and 
Micrococcus luteus FI10640 (MRS, $37{ }^{\circ} \mathrm{C}$, aerobic, static). Media was sourced from Oxoid (Hampshire, UK).

\section{In silico identification of bacteriocin gene clusters}

The L. gasseri LM19 genome was analysed with software to identify putative bacteriocin clusters: BAGEL 3 and BAGEL 4 (van Heel et al. 2013) to target bacteriocin clusters and antiSMASH to target secondary metabolites (Weber et al. 2015). Genome data was visualised using Artemis (Carver et al. 2012). DNA and amino acid sequences identified as putative bacteriocin genes and proteins were analysed using BLAST (Altschul et al. 1990) using default parameters. Geneious Tree Builder v11.1 (Biomatters Ltd., Auckland, New Zealand) was used to compare the gassericins.

\section{Detection and purification of antimicrobial peptides}

L. gasseri LM19 was grown anaerobically at $37{ }^{\circ} \mathrm{C}$ in 21 MRS broth for $24-48 \mathrm{~h}$. The culture was centrifuged $\left(8000 \times \mathrm{g}, 20 \mathrm{~min}, 10^{\circ} \mathrm{C}\right)$, and cells and supernatant were analysed independently. The cell pellet was resuspended in $400 \mathrm{ml}$ IPA (70\% propan-2-ol, $0.1 \%$ trifluoroacetic acid) for 3-4 h at room temperature, centrifuged again and the supernatant retained for further purification. This sample was tested for antimicrobial activity using L. bulgaricus LMG 6901 as an indicator and was also analysed directly by matrix assisted laser deionisationtime of flight-mass spectrometry (MALDI-TOF-MS; Axima TOF $^{2}$ MALDI-TOF mass spectrometer in positive-ion reflectron mode, Shimadzu Biotech, Manchester, UK) to determine the masses of the potential peptides. For further purification, IPA was removed by rotary evaporation until the sample volume was $120 \mathrm{ml}$; this was applied to a $2 \mathrm{~g} 12 \mathrm{ml} \mathrm{Strata}{ }^{\circledR} \mathrm{C}_{18}$-E solid-phase extraction (C18-SPE) column (Phenomenex, Macclesfield, Cheshire, UK), pre-equilibrated with methanol and water following manufacturer's instructions. The column was washed with $20 \mathrm{ml} \mathrm{30 \%}$ ethanol, then $20 \mathrm{ml}$ $30 \%$ acetonitrile and the active fraction was eluted with $30 \mathrm{ml}$ IPA. The IPA was removed as before and $4 \mathrm{ml}$ aliquots were applied to a semi preparative Jupiter C5 Reversed Phase HPLC column $(10 \times 250 \mathrm{~mm}, 10 \mu \mathrm{m}$, $300 \AA$, Phenomenex) ("HPLC fractionation I") running a $30-70 \%$ acetonitrile, $0.1 \%$ formic acid (FA) gradient over 95 min where buffer A is $0.1 \%$ FA and buffer B is $100 \%$ acetonitrile, $0.1 \%$ FA. Flow rate was $2.5 \mathrm{ml} / \mathrm{min}$, and fractions were collected at 1-min intervals and further analysed by MALDI-TOF-MS.

For purification from the cell-free supernatant, the supernatant was applied to an Econo-column (BioRad, Watford, UK) containing $60 \mathrm{~g}$ Amberlite XAD $16 \mathrm{~N}$. The column was washed with $400 \mathrm{ml} \mathrm{35 \%}$ ethanol followed by $400 \mathrm{ml}$
$30 \%$ acetonitrile and antimicrobial activity eluted with $450 \mathrm{ml}$ IPA. IPA was removed by rotary evaporation until the sample volume was $145 \mathrm{ml}$; this was applied to a $5 \mathrm{~g} 20 \mathrm{ml} \mathrm{C} 18$-SPE column pre-equilibrated with methanol and water. The column was washed with $30 \mathrm{ml} \mathrm{30 \%}$ ethanol followed by $30 \mathrm{ml} \mathrm{30 \%}$ acetonitrile and antimicrobial activity eluted with $30 \mathrm{ml}$ IPA and fractionated by semi-preparative reversed phase HPLC as before. To increase purity, some HPLC fractions were reapplied to the $\mathrm{C} 5 \mathrm{semi}$ prep column, running shallower gradients ("HPLC fractionation II") (30-40\% acetonitrile, $0.1 \%$ FA gradient over 95 min for GamX and Bact $2,30-45 \%$ gradient for GamA, and 35-65\% gradient for Bact 1 , GamM and GamY).

Additionally, the six peptides were synthesised using microwave-assisted solid phase peptide synthesis on a Liberty Blue microwave peptide synthesiser (CEM Corporation, Charlotte, NC, USA). GamA and GamM were synthesised on H-Lys (BOC)-HMPB-ChemMatrix ${ }^{\circledR}$ resin, GamX was synthesised on H-Asn(Trt)-HMPBChemMatrix ${ }^{\circledR}$ resin, Bact_1 and Bact_2 on H-Arg(PBF)HMPB-ChemMatrix ${ }^{\circledR}$ resin and GamY on Fmoc-PheWang (Novobiochem ${ }^{\circledR}$, Darmstadt, Germany) resin. Crude peptide was purified using RP-HPLC on a Semi Preparative Vydac C4 $(10 \times 250 \mathrm{~mm}, 5 \mu, 300 \AA)$ column (Grace, Chicago, Illinois, USA) running acetonitrile, $0.1 \%$ trifluoroacetic acid gradients specific to the peptide of interest. Fractions containing the desired molecular mass were identified using MALDI-TOF-MS and were pooled and lyophilised on a Genevac HT 4X lyophiliser (Genevac Ltd., Ipswich, UK). All naturally produced peptides and synthetic peptides were assayed by well-diffusion assay using L. bulgaricus DPC6901.

\section{Fermentation studies}

L. gasseri LM19 was inoculated at $1 \%$ in $20 \mathrm{ml}$ of prepared in-house MRS without glucose $(10 \mathrm{~g} / 1$ trypticase peptone (Difco, Wokingham, UK), $2.5 \mathrm{~g} / \mathrm{l}$ yeast extract (Difco), $3 \mathrm{~g} /$ $1 \mathrm{~K}_{2} \mathrm{HPO}_{4}, 3 \mathrm{~g} / 1 \mathrm{KH}_{2} \mathrm{PO}_{4}, 2 \mathrm{~g} / 1$ tri-ammonium citrate, $0.2 \mathrm{~g} / 1$ pyruvic acid, $0.3 \mathrm{~g} / 1$ cysteine- $\mathrm{HCl}, 0.575 \mathrm{~g} / 1$ $\mathrm{MgSO}_{4} \cdot 7 \mathrm{H}_{2} \mathrm{O}, 0.12 \mathrm{~g} / \mathrm{l} \mathrm{MnSO}_{4} \cdot 7 \mathrm{H}_{2} \mathrm{O}, 0.034 \mathrm{~g} / 1 \mathrm{FeSO}_{4}$ $7 \mathrm{H}_{2} \mathrm{O}$ and $1 \mathrm{ml}$ Tween 80 (all from Sigma-Aldrich, Gillingham, UK)), or batch model media, prepared as described previously (Parmanand et al. 2019). The $\mathrm{pH}$ was adjusted to 6.8 in both media and filter sterilised carbohydrate (glucose, lactose, galactose, inulin, starch or pectin [Sigma]) was added at $2 \%$ after autoclaving. Fermentations were incubated in anaerobic conditions at $37{ }^{\circ} \mathrm{C}$ over $48 \mathrm{~h}$, conducted in triplicate and $2 \mathrm{ml}$ samples collected at $24 \mathrm{~h}$ and $48 \mathrm{~h}$. One millilitre was used for enumeration by plate count, $\mathrm{pH}$ measurement using a $\mathrm{pH}-000-85282$ probe (Unisense, Aarhus, Denmark) and, once filter sterilised, well diffusion assay and $1 \mathrm{ml}$ for RNA extraction. 


\section{Nucleic acid extraction and sequencing}

Samples for RNA extraction were mixed with two volumes of RNAlater (Sigma-Aldrich), centrifuged for $10 \mathrm{~min}$ at $18,000 \times g$ at $4{ }^{\circ} \mathrm{C}$ and pellets stored at $-80{ }^{\circ} \mathrm{C}$. Extraction was performed using the RNeasy extraction kit (Qiagen, Manchester UK) with minor modifications. Pellets were resuspended in $1 \mathrm{ml}$ RLT buffer, supplemented with $10 \mu \mathrm{l} \beta$ mercaptoethanol (Millipore) and transferred to lysing matrix E tubes (MP Biomedicals, Loughborough, UK). Samples were lysed in a FastPrep-24 homogeniser (MP Biomedicals) by applying 2 pulses of $30 \mathrm{~s}$ and intensity 6.0 with $1 \mathrm{~min}$ on ice between pulses. Samples were centrifuged for $10 \mathrm{~min}$ at $17,000 \times g$ and the supernatant transferred to clean $15 \mathrm{ml}$ tubes and mixed with an equal volume of $70 \%$ ethanol. Seventy percent of the mixture, including any precipitate, was transferred to spin tubes and centrifuged at $8000 \times g$ for $1 \mathrm{~min}$ and following steps were as the manufacturer's instructions. RNA was eluted in $100 \mu \mathrm{l}$ RNase-free water and quantified by NanoDrop 2000 (Thermo Scientific, Gloucester, UK). DNase treatment was performed using the Turbo DNA-free ${ }^{\mathrm{TM}}$ kit (Invitrogen, Inchinnan, UK).

Genomic DNA was extracted using genomic tip-20 and genomic buffer set kits (Qiagen). Metagenomic DNA was extracted using the FastDNA Spin Kit for Soil (MP Biomedicals) following manufacturer's guidelines. Total DNA concentration was measured by Qubit 3 (Invitrogen). The V4 region of the 16S rRNA gene was used for high-throughput sequencing using the Illumina MiSeq platform. Data analysis was conducted using Quantitative Insights into Microbial Ecology (QIIME2 version 2018.11) (Bokulich et al. 2018).

\section{Quantitative PCR (qPCR)}

qPCR was used to detect the presence or absence of C. perfringens (Nagpal et al. 2015) and L. gasseri LM19 bacteriocin genes (Treven et al. 2013). Primers (Table 1, Sigma Genosys, Haverhill, UK) were designed using Primer 3 (v. 0.4.0) (Untergasser et al. 2012) and Netprimer (Premier Biosoft, San Francisco, California, USA) and tested using genomic DNA. Thermal cycling was performed using a Verity 96 well Thermal Cycler (Applied Biosystems, Cheshire, UK) using GoTaq G2 DNA polymerase (Promega, Chilworth, UK) according to manufacturer's instructions. Reaction conditions were $20 \mathrm{~s}$ at $95^{\circ} \mathrm{C}, 40$ cycles of $1 \mathrm{~s}$ at $95^{\circ} \mathrm{C}, 20 \mathrm{~s}$ at $60^{\circ} \mathrm{C}$ and $15 \mathrm{~s}$ at $95^{\circ} \mathrm{C}$, and a melt curve of 15 min at $65{ }^{\circ} \mathrm{C}$. dNTPs were provided by Bioline (London, UK). PCR products were visualised using 2\% agarose gels. A standard curve for C. perfringens NCTC 3110 was constructed by extracting gDNA as described previously (Ladero et al. 2011) from a culture with known colonyforming units (cfu)/ml of $C$. perfringens NCTC 3110 then performing serial dilutions. Each DNA concentration was measured using qPCR to determine the cycle signal associated with each cell concentration.

\section{Quantitative reverse transcription PCR (RT-qPCR)}

cDNA synthesis was carried out using the QuantiTect ${ }^{\circledR}$ Reverse Transcription Kit (Qiagen, UK) using 100 ng RNA per reaction. RT-qPCR was performed using 384-well plates (4titude Ltd., Dorking, UK) in the ViiA ${ }^{\text {TM }} 7$ System (Applied Biosystems) with the SensiFASTTM SYBR ${ }^{\circledR}$ No-ROX Kit (Bioline, London, UK). Reaction mix composition was, in $6 \mu \mathrm{l}, 0.6 \mu \mathrm{l}$ of cDNA template, $3 \mu \mathrm{l}$ of $2 \mathrm{x}$ SensiFAST SYBR ${ }^{\circledR}$ No-ROX mix, $0.24 \mu$ lof each primer $(10 \mu \mathrm{M}$ stock $)$ and $1.92 \mu \mathrm{l}$ of water. Reaction conditions were as qPCR. Reactions were set up in duplicate and the baseline for change was 2-fold relative to housekeeping gene gyrase $A$.

\section{Transformation of L. gasseri LM19}

Electro-competent cells of L. gasseri LM19 were made based on the method described previously (Holo and Nes 1989). Competent cells were resuspended in $2.25 \mathrm{ml} 10 \%$ glycerol/ $0.5 \mathrm{M}$ sucrose, aliquoted in volumes of $40 \mu \mathrm{l}$ and either used immediately or frozen on dry ice. Five hundred nanograms of plasmid pUK200 (Wegmann et al. 1999) were added to $40 \mu \mathrm{l}$ of electro-competent cells. The mixture was incubated for $1 \mathrm{~min}$ on ice and transferred to a pre-chilled electroporation cuvette (Geneflow Limited, Lichfield, UK). A pulse of $1500 \mathrm{~V}, 800 \Omega$ and $25 \mu \mathrm{F}$ was applied using a BioRad electroporator (Watford, UK). Four hundred fifty microlitres of pre-chilled MRS/ $20 \mathrm{mM} \mathrm{MgCl} / 2 \mathrm{mM} \mathrm{CaCl}_{2}$ were added to the cuvette, and the mixture transferred to a chilled 2-ml tube and incubated for $2 \mathrm{~h}$ at $37{ }^{\circ} \mathrm{C}$. Aliquots were plated on MRS with $7.5 \mu \mathrm{g} / \mathrm{ml}$ chloramphenicol and incubated overnight at $37{ }^{\circ} \mathrm{C}$. Transformants were confirmed by colony PCR using Go Taq G2 polymerase and primers p181 (5'GCGAAGATAACAGTGACTCTA-3' and p54 (5'-CGGC TCTGATTAAATTCTGAAG-3').

\section{In vitro colonic batch model fermentation}

Fermentations to simulate human colon conditions were performed as described previously (Parmanand et al. 2019). Experiments were carried out using three different faecal donors, one fermentation for each donor. Each faecal fermentation comprised 4 vessels-control, inoculation with $L$. gasseri, inoculation with $C$. perfringens, co-inoculation with both $L$. gasseri and C. perfringens. Overnight cultures of L. gasseri LM19 pUK200 and C. perfringens NCTC 3110 were added to the vessels at $1 \%$ each. Six-millilitre samples were extracted at $0 \mathrm{~h}, 4 \mathrm{~h}, 8 \mathrm{~h}, 24 \mathrm{~h}$ and $48 \mathrm{~h}$ for DNA and RNA extractions, SCFA analysis and, from those vessels 
Table 1 Primers for qPCR and RT-qPCR studies in L. gasseri LM19 and detection of C. perfringens

\begin{tabular}{|c|c|c|c|c|c|}
\hline Gene & Accession number & Primer & Sequence $\left(5^{\prime}-3^{\prime}\right)$ & Product size & Reference/accession no. \\
\hline gyrase A L. gasseri LM19 & 7791_LM19_00854 & $\begin{array}{l}\text { LGgyrAF } \\
\text { LGgyrAR }\end{array}$ & $\begin{array}{l}\text { TTGATTGCCTTAACCCTTCG } \\
\text { TTCCCATTGAACGAACATCA }\end{array}$ & 136 & This work \\
\hline bact_l & 7791_LM19_00792 & $\begin{array}{l}\text { Cluster } 1.1 \mathrm{~F} \\
\text { Cluster } 1.1 \mathrm{R}\end{array}$ & $\begin{array}{l}\text { TATTGGTGCATGGAGAGGTG } \\
\text { CCAGCCCACACATTGTACTG }\end{array}$ & 124 & This work \\
\hline bact_2 & 7791_LM19_00793 & $\begin{array}{l}\text { Cluster1.2F } \\
\text { Cluster1.2R }\end{array}$ & $\begin{array}{l}\text { TTGGGGTAGTGTTGCAGGAT } \\
\text { TGATGTTGCAGCTCCGTTAG }\end{array}$ & 97 & This work \\
\hline helveticin J-like & 7791_LM19_00025 & $\begin{array}{l}\text { Cluster2F } \\
\text { Cluster2R }\end{array}$ & $\begin{array}{l}\text { CTTGGGTACAAAGCGGAGAA } \\
\text { GCCTGCTCGGTTAAGATAAG }\end{array}$ & 176 & This work \\
\hline $\operatorname{gamA}(=\operatorname{gas} T)$ & 7791_LM19_00116 & $\begin{array}{l}\text { Cluster3.1F } \\
\text { Cluster3.1R }\end{array}$ & $\begin{array}{l}\text { CTGGATGGGCTCTTGGAAAT } \\
\text { TTTCCGAATCCACCAGTAGC }\end{array}$ & 112 & This work \\
\hline $\operatorname{gam} X(=\operatorname{gat} X)$ & 7791_LM19_00117 & $\begin{array}{l}\text { Cluster3.2F } \\
\text { Cluster3.2R }\end{array}$ & $\begin{array}{l}\text { TGGGGGAATGCTGTAATAGG } \\
\text { CTCCTAAGCCACAGGCAGTC }\end{array}$ & 100 & This work \\
\hline $\operatorname{gam} Y$ & 7791_LM19_00122 & $\begin{array}{l}\text { GamYF } \\
\text { GamYR }\end{array}$ & $\begin{array}{l}\text { ACTCAAATCGTAGGAGGAAAAGG } \\
\text { AAAGCATGCACCTGAACCA }\end{array}$ & 150 & This work \\
\hline gamM & 7791_LM19_00123 & $\begin{array}{l}\text { GasMF } \\
\text { GasMR }\end{array}$ & $\begin{array}{l}\text { AGCAGGAGGAGCATTTTCAA } \\
\text { CCTGCTGCACCACCTAAAAT }\end{array}$ & 90 & This work \\
\hline Immunity gene gamI3 & 7791_LM19_00118 & $\begin{array}{l}\text { Cluster 3.3F } \\
\text { Cluster 3.3R }\end{array}$ & $\begin{array}{l}\text { CAGATGAAGAAGCATTACTTGAAAA } \\
\text { TTCCAGGCCAAGTATTAGTTGTA }\end{array}$ & 102 & This work \\
\hline C. perfringens $16 \mathrm{~S}$ & MN960263 & $\begin{array}{l}\text { s-Clper-F } \\
\text { CIPER-R }\end{array}$ & $\begin{array}{l}\text { GGGGGTTTCAACACCTCC } \\
\text { GCAAGGGATGTCAAGTGT }\end{array}$ & 170 & (Nagpal et al. 2015) \\
\hline
\end{tabular}

where L. gasseri had been added alone, enumeration of L. gasseri LM19 pUK200 by plate count on MRS supplemented with $7.5 \mu \mathrm{g} / \mathrm{ml}$ chloramphenicol.

\section{SCFA analysis}

SCFA were measured using proton NMR (Parmanand et al. 2019). The metabolites were quantified using Chenomx NMR Suite v8.12 (Chenomx Inc., Edmonton, Canada) with the TSP concentration set to $0.1 \mathrm{mM}$.

\section{Statistical analysis}

Significant differences between groups were established using a paired $t$ test, assuming normal distribution, equal variances. Both sides of the distribution were considered. Significance was considered when the $p$ value was $<0.05$.

\section{Results}

\section{Antimicrobial activity}

The antimicrobial activity of L. gasseri LM19 was assessed against Gram-positive and Gram-negative pathogens (Table 2). The assay method affected the outcome, with the targets typically being more sensitive to LM19 grown on agar than to its cell free supernatant. The growth of $C$. perfringens NCTC 3110 and L. bulgaricus 5583 was inhibited by overlay assays. Cross-streaks showed antimicrobial activity against all
Gram-positive indicators and C. sakazakii, while supernatants exhibited activity by filter disc against L. bulgaricus, $C$. jejuni and $M$. luteus. Well-diffusion assay only inhibited the growth of L. bulgaricus. As L. bulgaricus was the most sensitive indicator, it was used in subsequent tests.

\section{Identification of bacteriocin gene clusters in the genome of $L$. gasseri LM19}

The sequenced genome of L. gasseri LM19 was assembled into contigs and submitted to the NCBI under accession number SHO00000000. AntiSMASH 3.0 indicated the presence of a single Microcin M-like cluster, while BAGEL 4, which specifically targets regions with bacteriocin similarities, found three clusters predicted to encode a number of potential bacteriocins. Manual investigation confirmed the presence of two clusters, whose putative structural peptides showed a high similarity to antimicrobial peptides from class IIb bacteriocins (clusters 1 and 3), and a helveticin-like protein (cluster 2). The latter contained no other bacteriocin-associated genes on the basis of Blastp analysis; the product of the single gene showed $31.9 \%$ identity and $43.1 \%$ amino acid consensus to helveticin $\mathrm{J}$, which was originally characterised in Lactobacillus helveticus following heterologous expression (Joerger and Klaenhammer 1986).

Cluster 1 (939 bp) has $99 \%$ nucleotide identity to the class IIb gassericin K7A cluster (EF392861). The cluster was predicted to encode two short peptides with leader sequences (Bact_1 and Bact_2) and a putative immunity protein (Fig. 1a). Bact_1 and Bact_2 show 100\% amino 
Table 2 Summary of inhibitory activity of L. gasseri LM19 using different techniques

\begin{tabular}{|c|c|c|c|c|c|}
\hline & Overlay & Cross-streak & Drop test & Filter disc & Well-diffusion \\
\hline S. enterica LT2 & - & - & - & - & - \\
\hline E. coli ATCC 25922 & - & - & - & - & - \\
\hline C. sakazakii NCTC 11467 & - & ++ & - & - & - \\
\hline C. perfringens NCTC 3110 & + & + & - & - & - \\
\hline L. innocua NCTC 11288 & - & ++ & - & - & - \\
\hline L. bulgaricus 5583 & +++ & +++ & - & ++ & +++ \\
\hline C. jejuni NCTC 11168 & $\mathrm{np}$ & $\mathrm{np}$ & $\mathrm{np}$ & + & $\mathrm{np}$ \\
\hline M. luteus FI10640 & - & ++ & - & + & - \\
\hline
\end{tabular}

-, no activity; + $1 \mathrm{~mm}$ radius inhibition zone;,$++ 1-5 \mathrm{~mm}$ radius inhibition zone;,$+++>5 \mathrm{~mm}$ inhibition zone; np, not performed

acid similarity with the gassericin $\mathrm{S}$ structural peptides GasA and GasX respectively (Kasuga et al. 2019), while the surrounding genes do not resemble any other genes associated with bacteriocin production. The putative immunity protein showed $97 \%$ amino acid homology to those of the acidocin LF221A and gassericin S clusters (Kasuga et al. 2019; Majhenič et al. 2004).

Cluster 3 is $9736 \mathrm{bp}$ and the first open reading frames (orfs) 1-8 show a high nucleotide homology to the gassericin $\mathrm{T}$ cluster from L. gasseri LA158 (AB710328, 99\% over 100\% coverage) and the gassericin E cluster from EV1461 (KR08485, 99\% over 95\% coverage) (Fig. 1a). There are two structural peptide-encoding genes, gamA and gamX, that are preceded by homologues of the gassericin E cluster as described previously (Maldonado-Barragán et al. 2016). It is likely that they perform the same predicted functions as their gassericin E homologues, i.e. $\operatorname{gam} P, \operatorname{gamK}, \operatorname{gamR}$ for

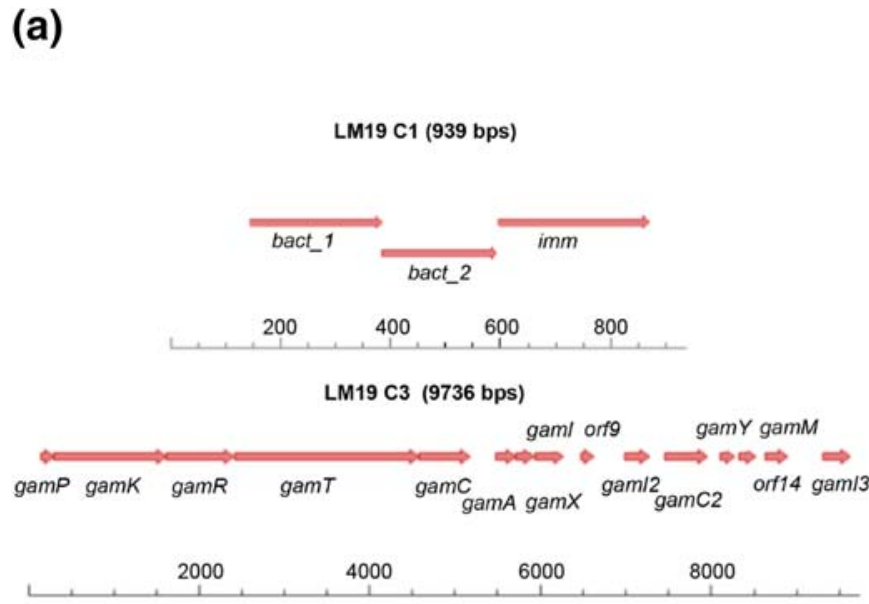

Fig.1 a Gene organisation in L. gasseri LM19 predicted bacteriocin cluster 1 (LM19 C1), encoding Bact_1 and Bact 2 and an immunity gene (imm), and cluster 3 (LM19 C3), encoding GamA, GamX, GamY regulation, gamT and $\operatorname{gam} C$ for transport and, after the structural peptides, gamI for immunity, although a homologue to gaeX is missing. The predicted GamA peptide has the same sequence as GasT, Gas K7B cf. and acidocin LF221B cf. and has a single amino acid difference (W-L) from GasE (Table 3). The second putative peptide, GamX, has the same sequence as GatX and GaeX, all of which differ by a single amino acid (GA) from Gas K7 B and acidocin LF221B (Table 3).

In cluster 3 , there are 7 further orfs including two additional putative structural genes, designated as gamM and gam $Y$, which appear to encode a further two-component bacteriocin. These putative peptides also show some similarity to other two-peptide component gassericins, but to a lesser extent (Fig. 1b). GamY shows similarity to GamM, with $25.4 \%$ identity and $47.6 \%$ consensus, and they both have similarity to $\mathrm{K} 7$ A cf. (27.5\% identity and $38.8 \%$ consensus; $25.3 \%$ identity, $44.3 \%$ consensus, respectively) and to GamA ( $18.7 \%$ identity,

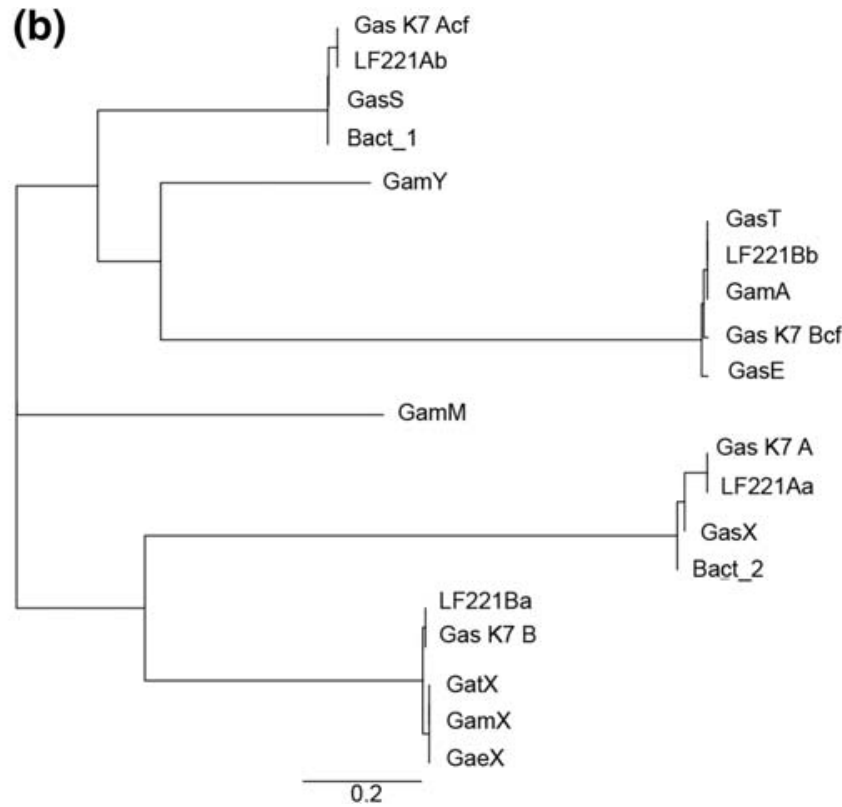

and GamM and accessory genes. b Phylogenetic tree of the amino acid sequences of putative bacteriocins identified in L. gasseri LM19 in context with other class IIb gassericins 


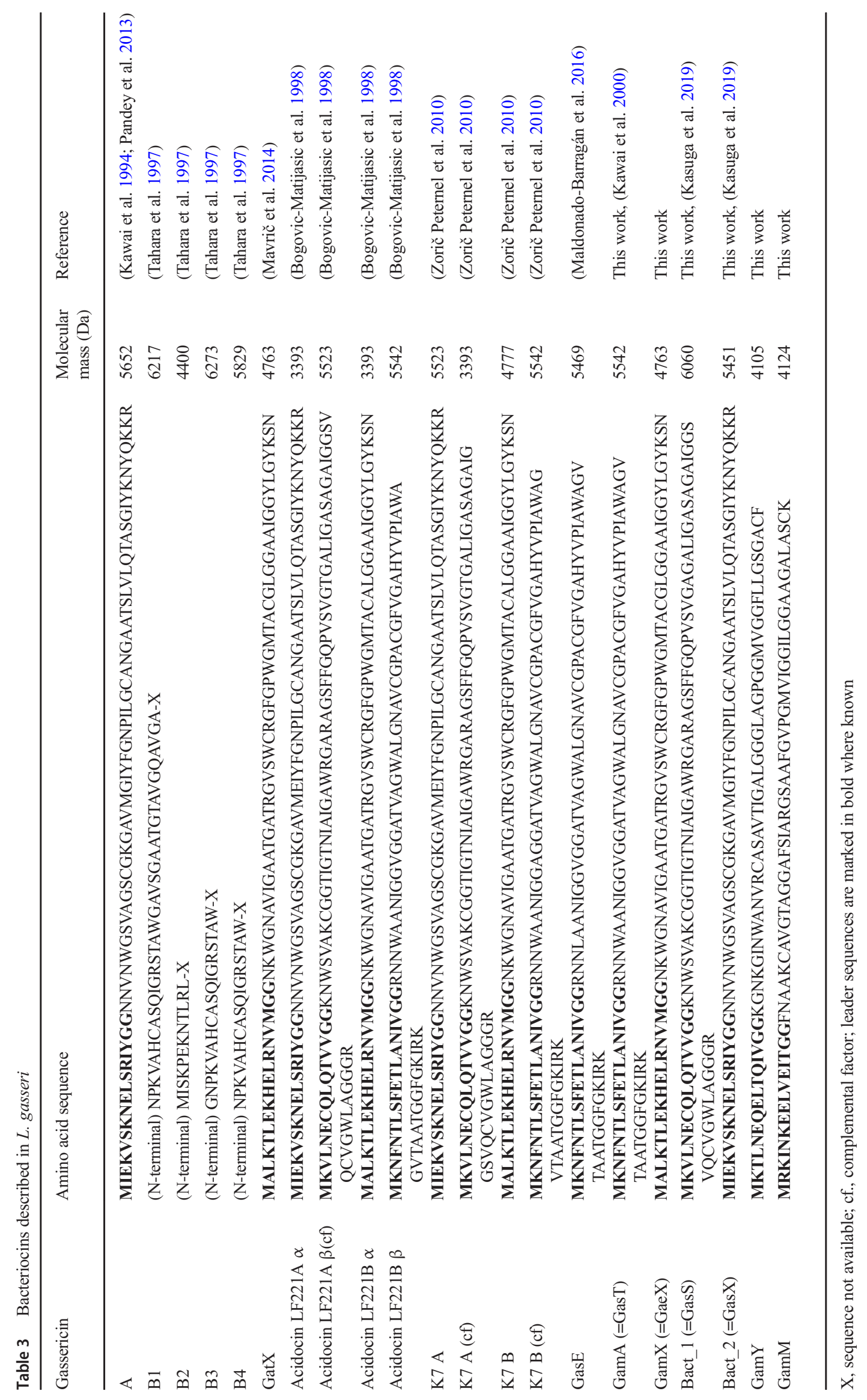


$33.3 \%$ consensus with GamM). Surrounding gam Yand gamM are two genes encoding putative immunity proteins, GamI2 and GamI3, with homology to an enterocin A immunity domain (pfam $08951,2.8 \mathrm{e}^{-7}$ and $1.1 \mathrm{e}^{-6}$, respectively), a putative transport accessory protein, GamC2, with some similarity to TIGR01295 bacteriocin transport accessory protein $\left(1.18 \mathrm{e}^{-9}\right)$, and thioredoxin superfamily cd02947 $\left(5.21 \mathrm{e}^{-7}\right)$, and two orfs with no matches. The genes on either side of the cluster show amino acid homology to transporters involved in solute or cation transport, and so are not predicted to be part of the cluster.

\section{Identification of antimicrobial peptides in culture}

Extraction of both cells and culture supernatants with IPA demonstrated the presence of antimicrobial activity in both samples (Fig. 2a), while MALDI TOF MS analysis of cell extracts demonstrated the presence of peptide masses that were consistent with those predicted by in silico analysis for GamM (4125 Da), GamY (4105 Da), Gam A (5541 Da), Bact 2 (5450 Da), Bact 1 (6059 Da) and Gam X (4765 Da) (Table 3, Fig. 2b). Further purification of these cell extracts by HPLC and analysis of fractions showing antimicrobial activity allowed separation of many of these masses (Fig. 3), identifying masses corresponding to putative GamX (4763 Da, Fig. 3a), GamA, (5541 Da, Fig. 3b), co-eluted GamY and GamM (4107 and 4126 Da respectively, Fig. 3c) and Bact_1 (6057 Da, Fig. 3d), while further purification (HPLC fractionation II) allowed the separation of GamM (4126 Da, Fig. 3e).

MS analysis of culture supernatant samples from HPLC fractionation I which showed antimicrobial activity identified a mass for Bact_2 (5451 Da, Fig. 3f).

\section{Antimicrobial activity of fractions and synergy between synthetic peptides}

The antimicrobial activities of three sets of fractions were compared, fractions from HPLC fractionation I of cell extracts (Supplemental Fig. S1), from HPLC fractionation II of these fractionation I samples (Supplemental Fig. S2), and synthetic peptides resuspended in milli Q water at $1 \mathrm{mg} / \mathrm{ml}$. MS profiles of all samples demonstrate that fractions contained separated masses corresponding to all six peptides, although the level of GamX was very low from HPLC fractionation I and HPLC fractionation II gave very small yields of GamY and GamM (Supplemental Fig. S3). All synthetic peptides except GamY

\section{(a)}
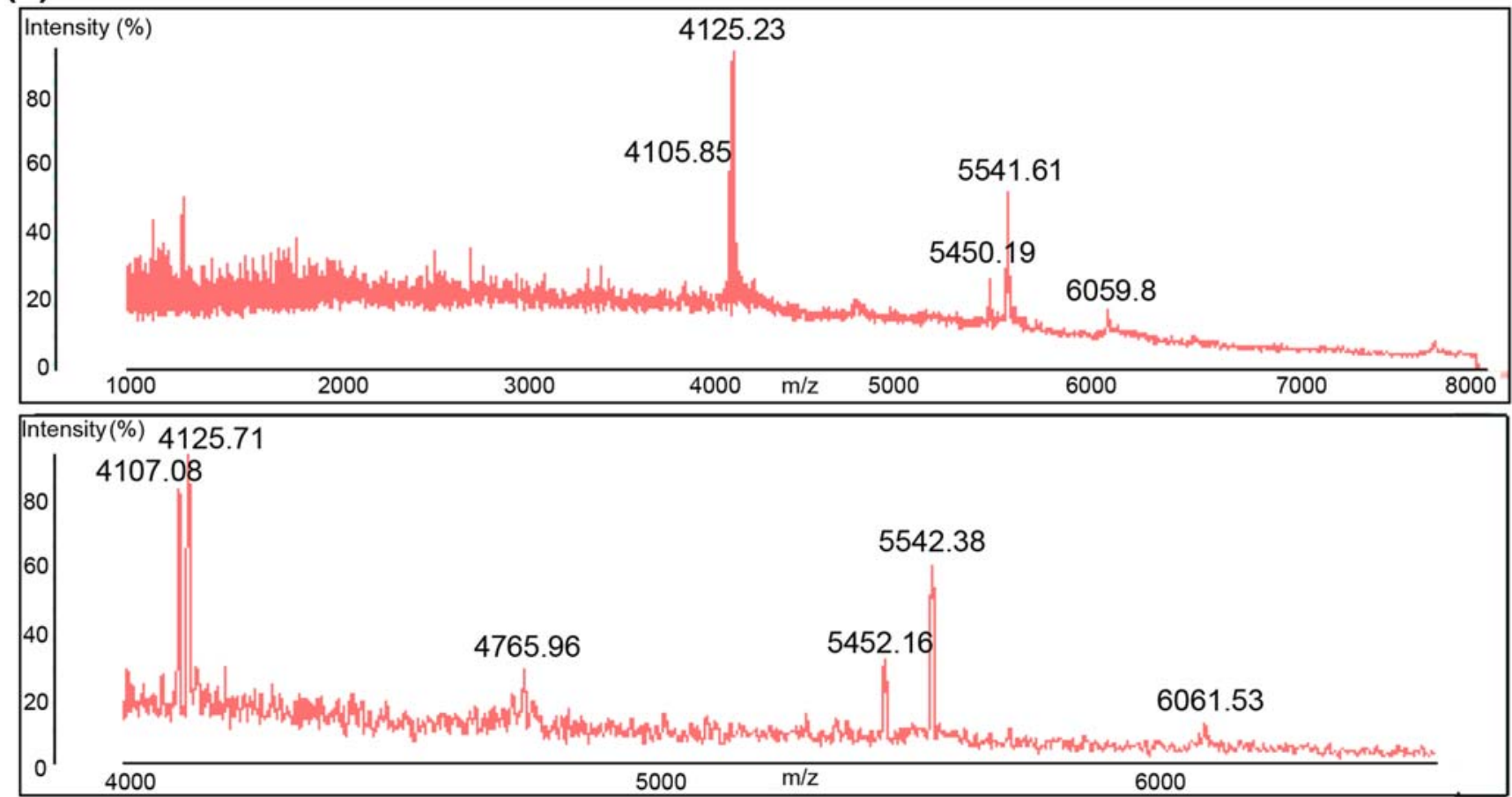

Fig. 2 a Antimicrobial activity of cell (C) and supernatant (SN) IPA extracts of L. gasseri LM19 culture. b Mass spectra showing masses of interest for the six peptides in two different cell extracts 
showed antimicrobial activity, with the highest activity coming from GamA and Bact 2 (Fig. 4a). Samples from HPLC fractionations also gave clear antimicrobial activity, with GamA and Bact_2 again giving the largest zones of inhibition, and here the fractions containing the mass for GamY showed clear activity (Fig. 4a). The low activity of GamX and, from the second fractionation, GamM, might be due to the low yields of the peptides, and variation in activity between fractionations I and II may also be due to differing yields in fractions (Supplemental Fig. S3). Figure $4 \mathrm{~b}$ and $\mathrm{c}$ show synergy assays between synthetic peptides. We observed clear synergy between Bact_1 and Bact_2 and a possible synergy between Bact_1 and GamA. No synergy was observed between GamM and GamY or between GamA and GamX. Control tests confirmed that IPA did not affect bacterial growth (data not shown).

\section{Complex carbohydrates can favour viability and antimicrobial activity of $L$. gasseri LM19}

L. gasseri LM19 was grown in colon batch model medium, simulating gut conditions, or home-made MRS, alone or supplemented with simple sugars (glucose, lactose and galactose) or complex polymers (inulin, starch and pectin). In general, more viable cells were recovered from MRS; growth on simple sugars was highest at $24 \mathrm{~h}$ but, at $48 \mathrm{~h}$, complex carbohydrates gave higher counts (Fig. 5a). Interestingly, growth in the absence of a carbon source at $48 \mathrm{~h}$ was similar to that with simple sugars. On batch model medium, cell counts with glucose were lower than with all other treatments, galactose produced the highest counts at $24 \mathrm{~h}$ while starch and pectin improved growth at $48 \mathrm{~h}$. Antimicrobial activity from batch model medium with glucose was almost as high as that from MRS despite a $\sim 3 \log$ difference in cfu (Fig. 5b). Glucose and galactose supplementation showed the highest antimicrobial activity at $24 \mathrm{~h}$, while complex carbohydrates inulin and pectin produced the highest activity after $48 \mathrm{~h}$.

The changes in activity with carbon supplementation over time suggest control of antimicrobial production in different nutritional environments. Examination of bacteriocin gene expression by RT-qPCR in MRS also showed that an absence of carbon supplementation increased the expression of gamM and $\operatorname{gam} Y$ significantly at $48 \mathrm{~h}$. Starch supplementation increased the expression of both genes at $24 \mathrm{~h}$, as did inulin at $48 \mathrm{~h}$. Galactose supplementation also produced a significant increase in expression of gamM at $48 \mathrm{~h}$ and $\operatorname{gam} Y$ at 24 and $48 \mathrm{~h}$ (Fig. 5c). Other bacteriocin genes did not show notable changes in expression, except for an increase in expression of the helveticin J-like gene in the presence of starch at $24 \mathrm{~h}$ (Supplementary Table S1).

\section{In vitro colon model fermentations with $L$. gasseri LM19}

\section{Survival of L. gasseri LM19 and C. perfringens in an in vitro colon model}

L. gasseri LM19 was transformed with a plasmid conferring chloramphenicol resistance to allow selection and enumeration of this strain within a mixed microbial community. Transformation of electrocompetent cells gave an efficiency of $1.07 \times 10^{2}$ transformants/ng of DNA. Fermentations with three different faecal donors were performed on three separate occasions with four vessels per fermentation inoculated with L. gasseri LM19-pUK200, C. perfringens NCTC $3110, L$. gasseri with C. perfringens, or a media control. Viable L. gasseri counts were measured in the treatment vessel inoculated with $L$. gasseri LM19-pUK200 alone by selective plating. The numbers recovered increased from 5.30, 5.22 and $5.22 \log _{10} \mathrm{cfu} / \mathrm{ml}$ in donors 1,2 and 3 , respectively at $4 \mathrm{~h}$, to $6.12,6.39$ and $6.36 \log _{10} \mathrm{cfu} / \mathrm{ml}$ at $8 \mathrm{~h}$ and 7.30 , 7.31 and $7.47 \log _{10} \mathrm{cfu} / \mathrm{ml}$ at $24 \mathrm{~h}$. However, after $48 \mathrm{~h}$, levels of recovery dropped to $3.66,4.00$ and $3.72 \log _{10}$ $\mathrm{cfu} / \mathrm{ml}$. It was not possible to assess L. gasseri LM19 counts in the $C$. perfringens co-inoculated vessel, as $C$. perfringens was able to grow on the selective plates. However, analysis of L. gasseri LM19 housekeeping gene gyrase A mRNA levels by RT-qPCR showed that copy numbers were similar in vessels treated with either L. gasseri LM19 alone or with L. gasseri with C. perfringens (data not shown).

C. perfringens levels were measured by qPCR, which detects DNA from both live and dead cells. Addition of L. gasseri LM19 did not have a negative effect on the C. perfringens population in the fermentation with faecal sample from donor 1 ; there was a tendency to lower $C$. perfringens counts in co-culture at $24 \mathrm{~h}$ with donors 2 and 3, but the changes were not significant (Fig. 6a).

\section{Bacteriocin gene expression}

RT-qPCR was used to detect expression of the bacteriocin genes bact_1, bact_2, helveticin-J like, gamA, gamX, gam $M$ and gam $Y$, compared to housekeeping gene gyrase $A$. This showed detectable levels of bacteriocin gene expression at $24 \mathrm{~h}$ both in the vessel where L. gasseri LM19 was inoculated alone and in co-culture with C. perfringens (Fig. 6b). Primers specific to $C$. perfringens only identified a signal in the two vessels where $C$. perfringens had been inoculated. At $48 \mathrm{~h}$, expression of only helveticin-J like, gamM and gamY genes was detected (data not shown). 
(a)

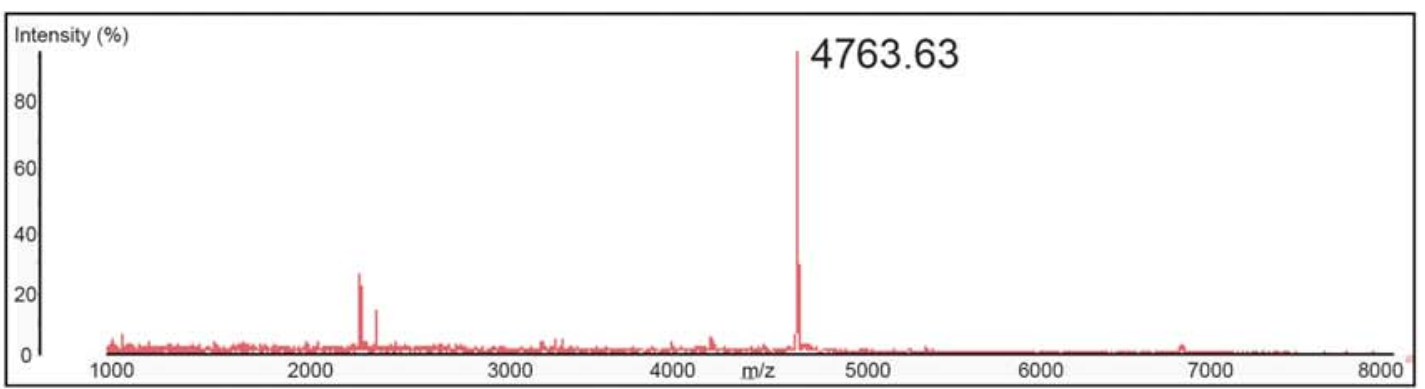

(b)

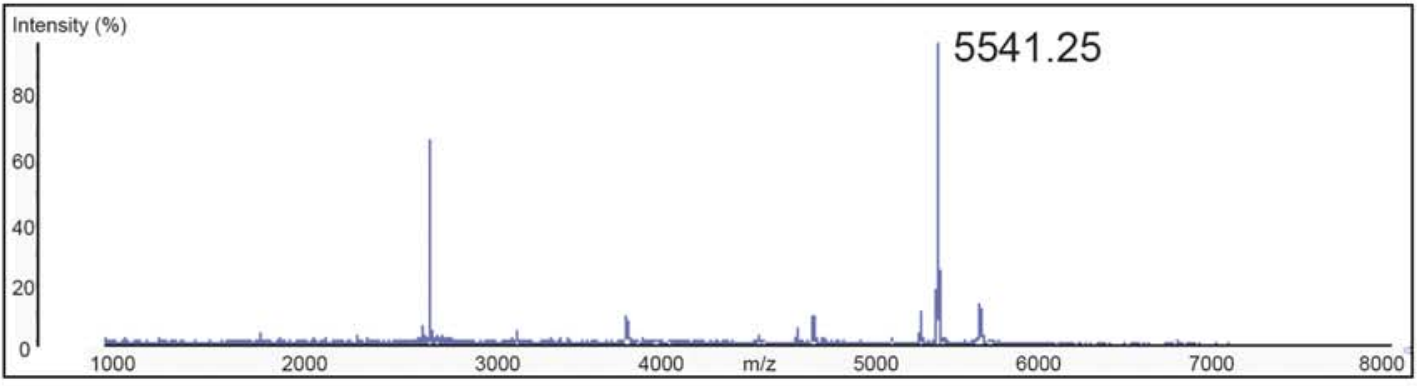

(c)

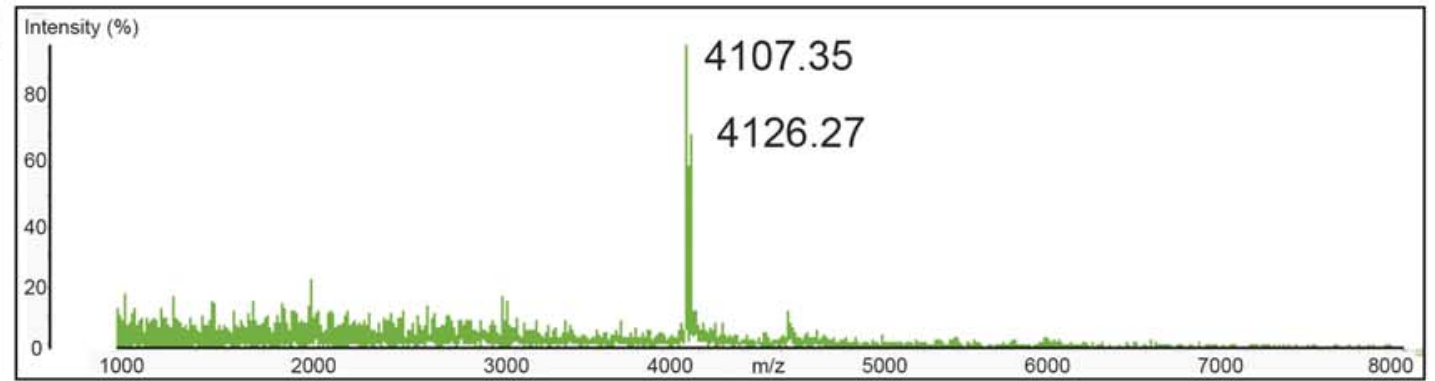

(d)

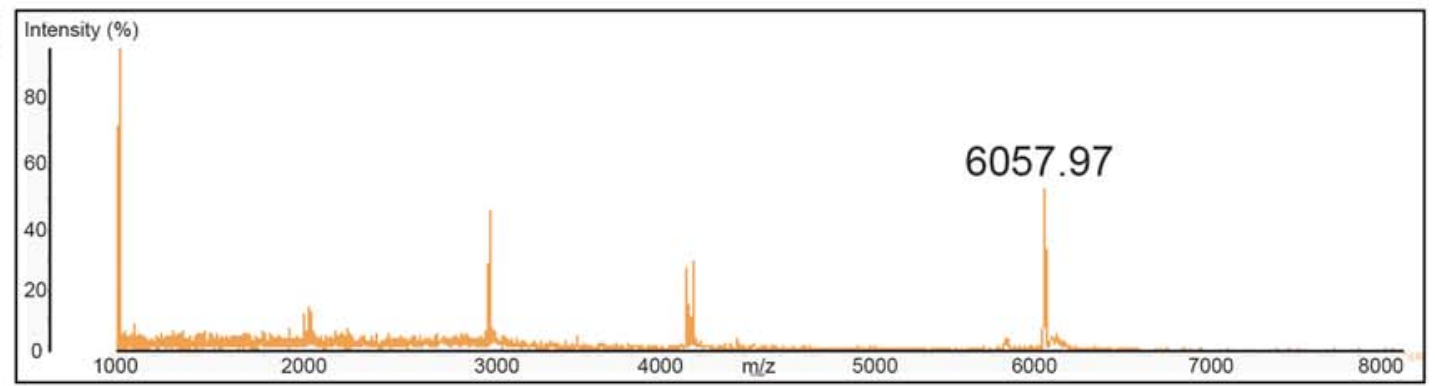

(e)

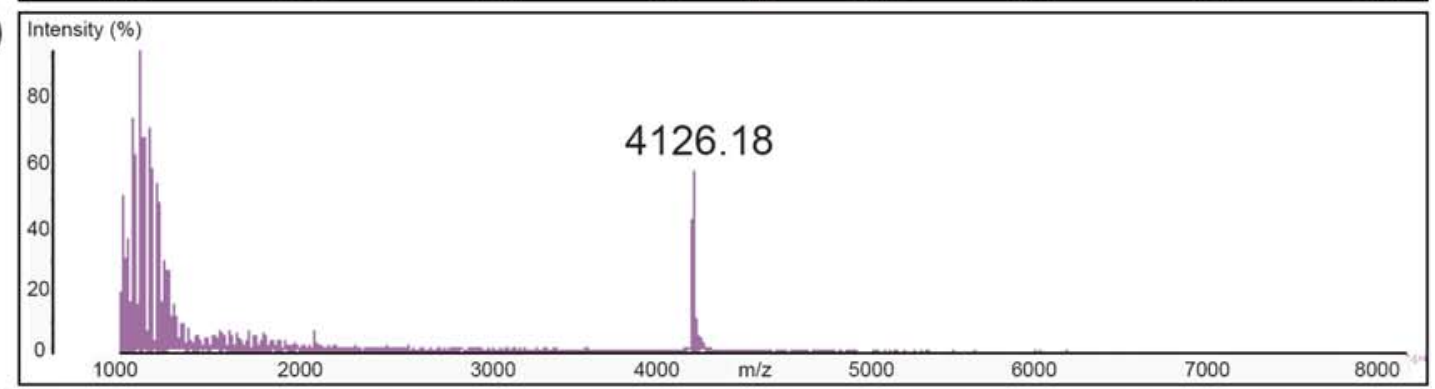

(f)

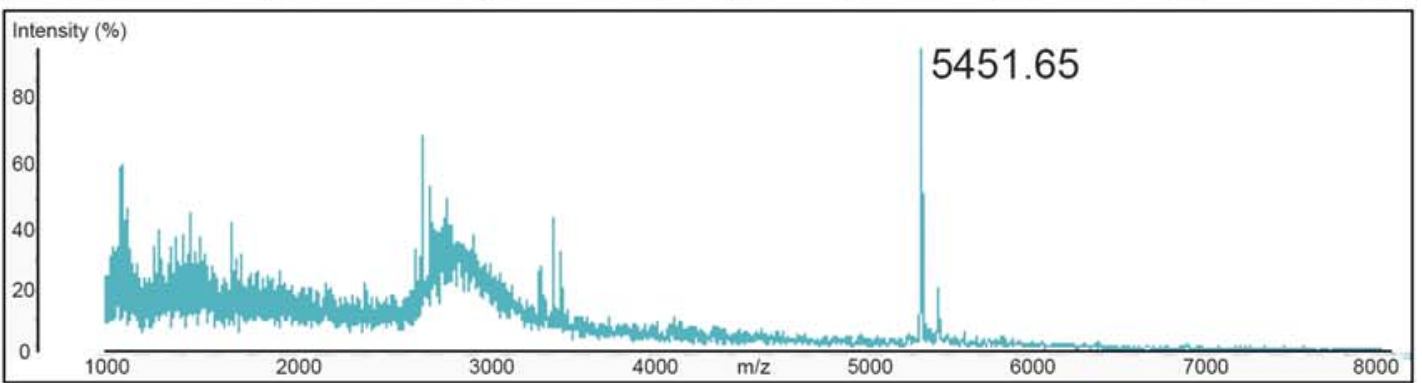


Fig. 3 MS spectra of active fractions from HPLC-purified cell extracts (a-e) and supernatant (f). Cell extract samples purified by HPLC fractionation I showed putative masses for a GamX, 4763 Da; b GamA, $5541 \mathrm{Da} ; \mathbf{c}$ GamM, $4126 \mathrm{Da}$ and GamY, $4107 \mathrm{Da}$; d Bact_1, $6057 \mathrm{Da}$; e putative GamM, $4126 \mathrm{Da}$, was separated from GamY by HPLC fractionation II; $\mathbf{f}$ a mass for Bact 2, $5451 \mathrm{Da}$, was identified after HPLC fractionation I of culture supernatant

\section{Impact of L. gasseri LM19 on gut microbiota composition}

Changes in the colon model microbiota were analysed by 16S rRNA metagenomic profiling. Analysis of relative abundance at order, family and genus level was conducted. The initial bacterial composition was, as expected, different between the three donors (Fig. 6c). Bacterial populations from donor 1 remained relatively stable over $24 \mathrm{~h}$. The addition of L. gasseri LM19, C. perfringens or both did not result in a significant increase in proportions of Lactobacillales or Clostridiales, and all 3 treatments resulted in similar increases in Bifidobacteriales and Coriobacteriales relative to the control, with the L. gasseri LM19 with $C$. perfringens co-treatment being more similar to the L. gasseri LM19 only condition.

The initial population from donor 2 was constituted mainly of Clostridiales, with some Bacteroidales, Coriobacteriales and

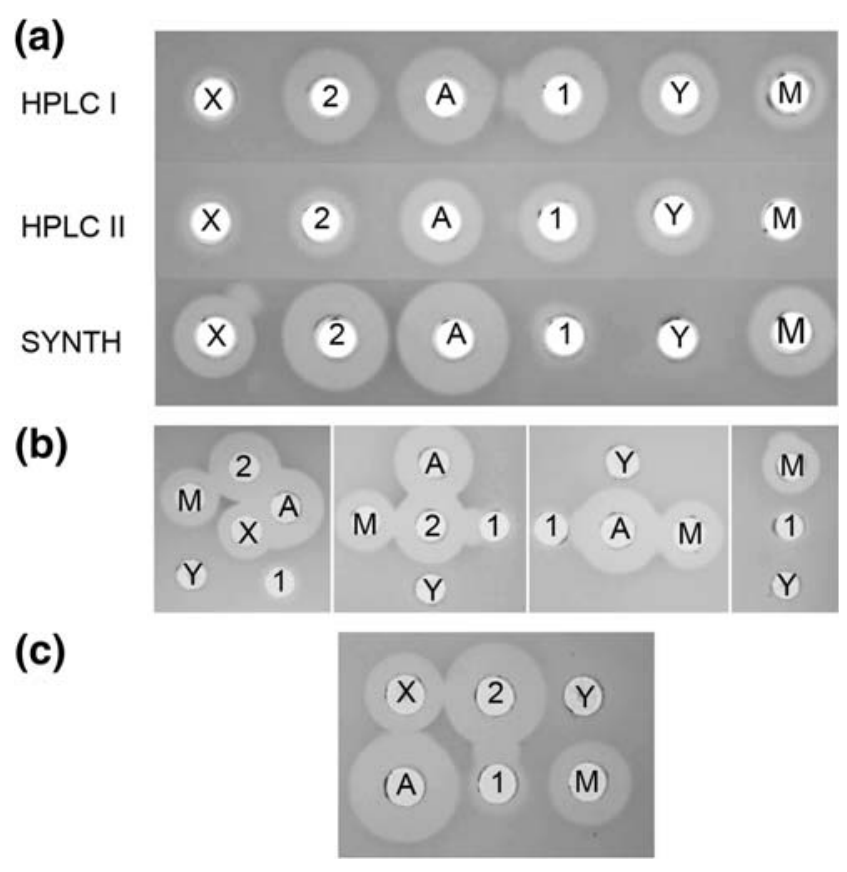

Fig.4 a Antimicrobial activity of fractions containing peptides of masses corresponding to GamX, (X); Bact_2, (2); GamA, (A); Bact_1, (1); GamY (Y); GamM, (M) from HPLC fractionation I (HPLC I), from cell extracts and supernatant, and from HPLC fractionation II (HPLC II) - MS chromatograms of these fractions are presented in Supplemental Fig. S3. Activity from HPLC fractionations I and II was compared with the activity of the synthetic peptides (SYNTH). b Synergy between the different synthetic peptides. c Synergy between pairs of synthetic peptides
Bifidobacteriales. A change can be observed at $24 \mathrm{~h}$ in both the control and the samples where L. gasseri LM19 or L. gasseri LM19 with C. perfringens were added, with an increase in Lactobacillales along with a small increase in Enterobacteriales. The decrease in relative abundance of Bifidobacteriales and Coriobacteriales in the control, $L$. gasseri and $C$. perfringens with $L$. gasseri treatments was statistically significant $(p<0.05)$ and not observed in the $C$. perfringens sample. C. perfringens alone appeared to prevent the overgrowth of Lactobacillales, while Clostridiales were decreased, being replaced by Enterobacteriales, Bacteroidales, Coriobacteriales and Bifidobacteriales. It was noted that addition of $L$. gasseri LM19 with $C$. perfringens gave a profile with more similarity to the control or L. gasseri LM19 only samples.

In L. gasseri LM19 treatment of donor 3 samples, Bifidobacteriales and Enterobacteriales increased over time in a similar way to the control, but Clostridiales were almost completely replaced by Lactobacillales. This rise was not as large when the L. gasseri LM19 was co-inoculated with $C$. perfringens, while addition of $C$. perfringens alone did not manage to maintain levels of Clostridales, with increases seen in Enterobacteriales, Bifidobacteriales and Lactobacillales. In this case, the L. gasseri LM19 with C. perfringens co-treatment at $24 \mathrm{~h}$ was more similar to the control, with the exception of the presence of Lactobacillales, suggesting that the $C$. perfringens effect on the microbial composition was changed by the inoculation with $L$. gasseri.

\section{Presence of $L$. gasseri LM19 increases SCFA content in a colon model environment}

Increases in the production of formic, acetic, propionic and butyric acids were observed in the three faecal fermentations in colon model conditions inoculated with L. gasseri LM9 alone compared to controls. However, there was a high variability in SCFA production between the three donors (Fig. 6d). In donor 1, production of SCFA, ethanol, succinate and, at $8 \mathrm{~h}$ only, lactate was increased compared to the control. In donor 2 there were notable increases in lactic acid from $4 \mathrm{~h}$. Given the similar relative abundance of Lactobacillales (Fig. $6 \mathrm{~d}$ ) in control and L. gasseri treatment, this suggests an influence of $L$. gasseri LM19 on the native microbiota. SCFA content in vessels inoculated with $C$. perfringens indicated that this bacterium also had the capacity to increase SCFA levels, while values from the co-inoculated vessels indicated that SCFA synthesis from each bacterium was not notably affected by co-inoculation (data not shown).

\section{Discussion}

In this study, we report the ability of a representative of the human breast milk microbiota to exhibit antagonistic activity 
Fig. 5 a Viable counts of L. gasseri LM19 recovered after growth in batch model media or home-made MRS supplemented with different carbon sources. $\mathbf{b}$ Antimicrobial activity of cultures in a measured by well diffusion assay (Figures above bars indicate mean $\mathrm{pH})$. $\mathbf{c}$ Gene expression levels of gam $M$ and gam $Y$ after L. gasseri LM19 was cultured in home-made MRS supplemented with different carbon sources. Expression values were normalised with those of housekeeping gene gyrase A. Values are relative to the gene expression measured in the glucose treatment, which was given the arbitrary value of 1 . No S, no supplementation; G, glucose; L, lactose; Gal, galactose; I, inulin; S, starch and P, pectin; *, significant difference to glucose supplementation $(p<0.05)$. Results are the mean of triplicate measurements \pm standard deviation

\section{(a)}
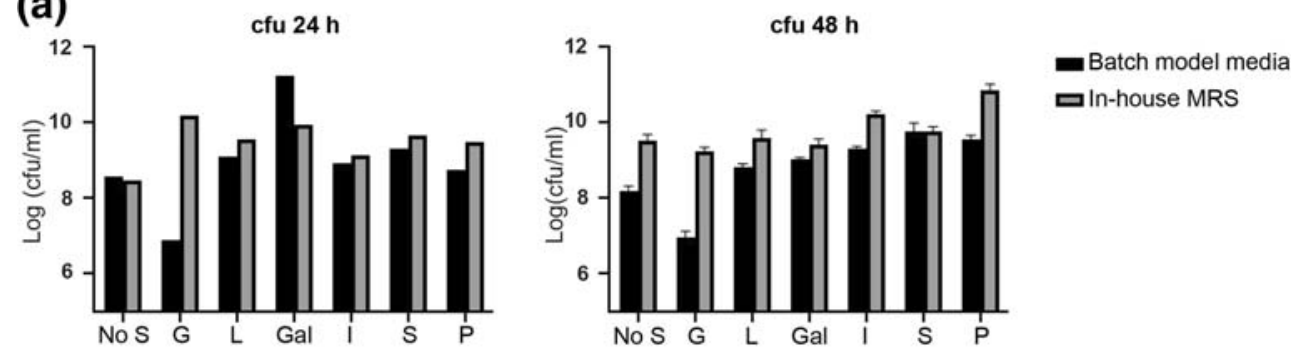

(b)
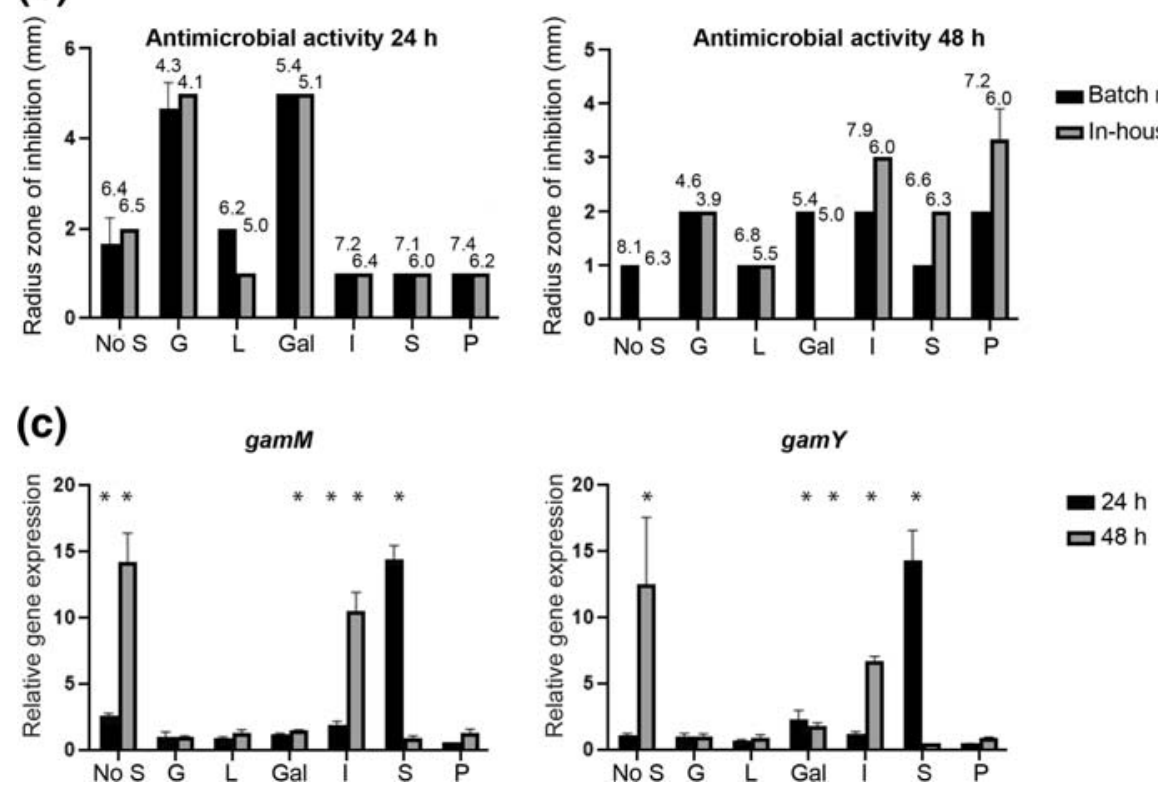

against different enteropathogens and to produce both previously identified bacteriocins and one novel bacteriocin. We observed that different carbon sources have an influence on the expression of these bacteriocin genes. L. gasseri LM19 survived and expressed these antimicrobial genes in a complex faecal environment under simulated colon conditions. This can be considered an important feature, since not all strains that exhibit probiotic traits are able to survive in colon conditions and, therefore, deliver their activity in situ. Additionally, we observed other characteristics that are considered useful, such as the production of SCFA.

Gassericins are antimicrobial peptides produced by L. gasseri. Several gassericins have been identified as twopeptide class II bacteriocins, and some isolates have been shown to contain pairs of two-peptide operons. These twopeptide bacteriocins also show similarities with other twopeptide bacteriocins isolated from species previously grouped with $L$. gasseri (Tahara et al. 1996). The genome of $L$. gasseri LM19 encodes a helveticin J-like protein and two gene clusters of two-peptide bacteriocins, encoding peptides that show homology to acidocin LF221A and Gas K7A (Bact_1 and Bact 2) or to acidocin LF221B and Gas K7B (Gam A and GamX). Additionally, in the second half of one of these clusters, we observed the presence of structural genes encoding GamM and GamY, corresponding to a new twocomponent bacteriocin that showed a greater variation in sequence to previously described gassericins. Although these structural genes were co-located with several putative immunity genes, there were no separate genes for regulation or transport, which suggests that like Gam A and GamX they may use the gamPKR and gamTC located in the same cluster.

MALDI TOF MS analysis of cell extracts confirmed that masses for all 6 peptides were present. Further HPLC fractionation showed that the masses could be separated and associated with antimicrobial activity. However, yields of the single peptides in fractions varied, and the presence of traces of other peptides could not be ruled out, so a direct comparison between activities was problematic. Accordingly, synthetic peptides were produced and assayed. With both HPLC fractions and synthetic peptides, GamA and Bact 2 consistently gave the highest antimicrobial activity, but the activity of synthetic GamM was still notable. It is interesting that synthetic GamY did not show activity, while HPLC fractions containing the GamY mass did - this may be due to trace levels of other peptides in the fraction, which may either 
(a)
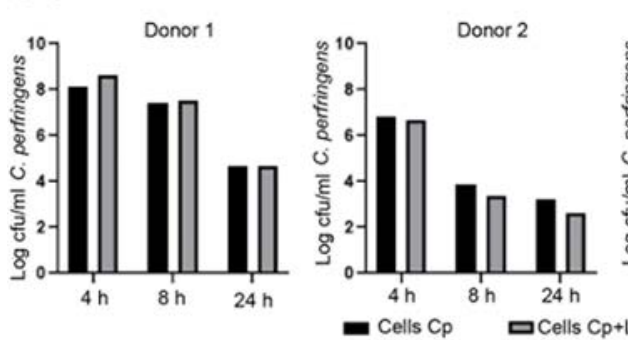

(b)
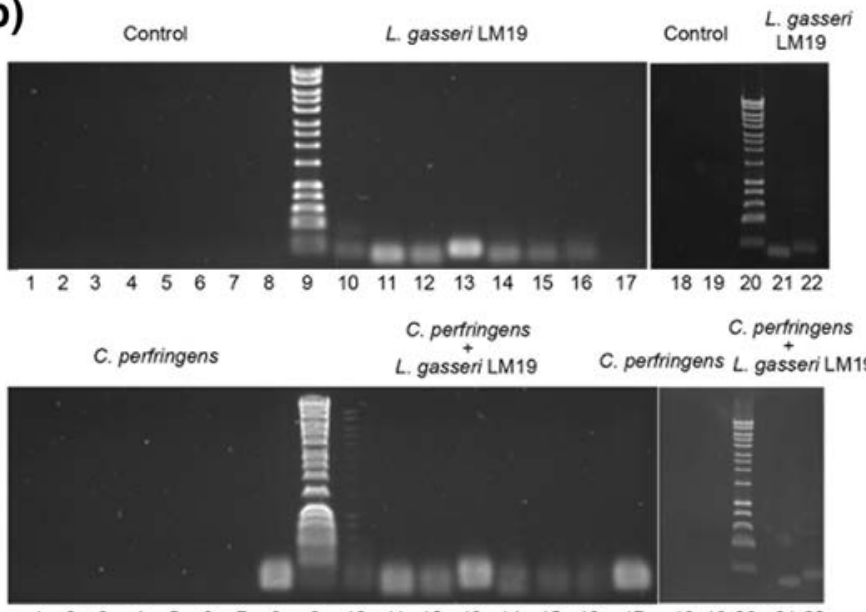

$\begin{array}{llllllllllllllllllllll}1 & 2 & 3 & 4 & 5 & 6 & 7 & 8 & 9 & 10 & 11 & 12 & 13 & 14 & 15 & 16 & 17 & 18 & 19 & 20 & 21 & 22\end{array}$

(d)
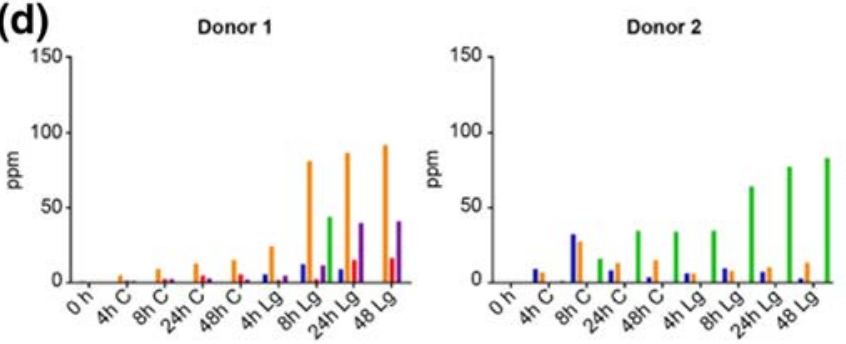

Fig. 6 In vitro colon model fermentations with L. gasseri LM19 and $C$. perfringens. a $C$. perfringens NCTC 3110 population measured by qPCR when inoculated alone $(\mathrm{Cp})$ or co-inoculated with $L$. gasseri LM19 $(\mathrm{Cp}+\mathrm{Lg})$ in three different fermentations with faeces from donors 1, 2 and 3. b Expression of bacteriocin genes in vessels from all 4 treatments (control, L. gasseri LM19 alone, C. perfringens alone, L. gassieri LM19 with $C$. perfringens) at $24 \mathrm{~h}$ in fermentations with faeces from donor 1: lane 1, negative control; lanes 2 and 10, bact 1; lanes 3 and 11, bact 2; lanes 4 and 12, gamA; lanes 5 and 13, gamX; lanes 6 and 14, helveticin J-like; lanes 7 and 15, gyrA; lanes 8 and 17, C. perfringens;

contribute their own activity or interact with GamY to facilitate its activity, or to a requirement for some further peptide processing which was not replicated by synthesis. Similarly, the activity for synthetic Bact_1 was lower than that from fractions containing the Bact_1 mass, presumably for the same reasons. Synergistic activity was reported previously between GasT and GatX and between the two components of gassericin S (here Bact_1 and Bact_2), respectively (Kasuga et al. 2019). It is possible that GamY requires the presence of one of the other
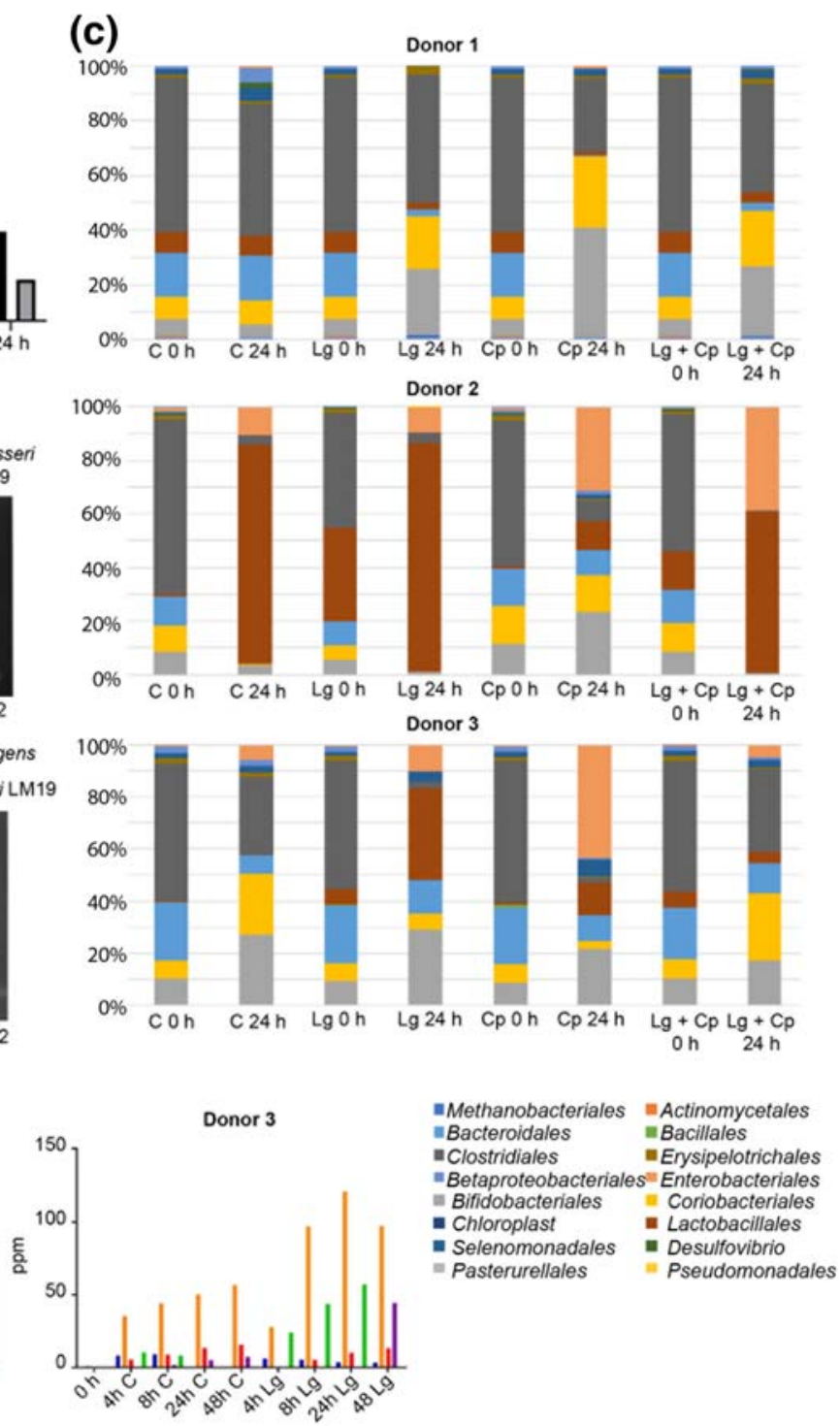

lanes 9 and 20, molecular marker; lanes 18 and 21, gamM; lanes 19 and 22, gamY. c Microbial profiles obtained by $16 \mathrm{~S}$ rRNA analysis showing relative abundance at the order level in the faecal batch model fermentation for the three donors (C, control, Lg, L. gasseri LM19 alone, Cp, C. perfringens alone, $\mathrm{Lg}+\mathrm{Cp}$, co-inoculation of L. gasseri LM19 and $C$. perfringens). d Production of SCFA in batch model faecal fermentations from control vessels $(C)$ and vessels inoculated with $L$. gasseri LM19 alone ( $\mathrm{Lg}$ ) using faecal inoculum from three different donors: blue, formate; orange, acetate; red, propionate; purple, butyrate; green, lactate

peptides, possibly GamM, for activity. However, examination of possibly synergy between peptides did not identify any activity from GamY when next to GamM. There was very clear synergy between Bact_1 and Bact_2, and possible synergistic activity between GamA and Bact_1, but the GasT and GatX homologues from this study, GamA and GamX, did not appear to affect each other.

Due to the production of multiple bacteriocins, the activity of single peptides, peptide pairs or possible synergistic reactions are challenging to assess. The antagonistic 
effect on tested pathogens suggest that these bacteriocins may have different targets or modes of action, as both Gram-positive and Gram-negative bacteria are affected and the nature of the test had an impact on the sensitivity. Although the expression of genes for GamM and GamY was shown to increase notably with different carbon sources, the antimicrobial activity of the culture did not follow the pattern of gamM and gam Y expression, indicating that the whole activity encompasses several if not all bacteriocins. Further analysis of a series of multigene knockouts which synthesise single peptides or pairs of peptides should give a clearer analysis of peptide activity and interaction.

The presence of bacteria in human breast milk has been reported previously and the existence of a bacterial entero-mammary pathway has recently been proposed (Rodríguez 2014). These bacteria might have a gut origin and that could explain their ability to survive in GI tract conditions and exhibit antagonistic traits against other gut bacteria, such as enteropathogens, that might share the same environment. This may also explain their ability to utilise complex carbohydrate polymers which are likely to be found in the gut environment, and the observed upregulation of bacteriocin genes $\operatorname{gam} M$ and $\operatorname{gam} Y$ in a low-sugar environment or with certain complex carbohydrates might produce a competitive advantage. In previous work it was demonstrated that another potentially probiotic $L$. gasseri, strain $\mathrm{K} 7$, which produced 2 two-peptide bacteriocins K7 A, K7 A (cf), K7 B and K7 B (cf), was able to survive in faecal samples. Its bacteriocins were also the focus of examination by conventional PCR and RT-PCR (Treven et al. 2013). In that instance, the authors noted that bacteriocin genes were amplified by PCR from other LAB species present in the environment. However, in our controls and treatments where L. gasseri LM19 was not present, no PCR products were detected.

L. gasseri LM19 showed mixed effects on a strain of C. perfringens added to faecal fermentations of three different donors, causing a slight decrease in C. perfringens in only 2 out of 3 fermentations. This might indicate that the surrounding microbiota plays a synergistic or antagonistic role on the effect of L. gasseri LM19. However, it should be noted that in antimicrobial assays $C$. perfringens was only inhibited by $L$. gasseri LM19 cells, not cell-free supernatant, which might suggest that they should be in close proximity for an antimicrobial effect. Co-inoculation of L. gasseri LM19 with $C$. perfringens did seem to alter the effect of $C$. perfringens on the background microbiota: in experiments with all three donors, the profiles seen after addition of L. gasseri LM19 with $C$. perfringens were more similar to instances where L. gasseri was added alone or in control samples than to samples containing only $C$. perfringens. Although we confirmed that bacteriocin genes were being expressed in these fermentations, other factors such as lactic acid production may also have an impact.

Colon model fermentations also allowed the production of formic, acetic, propionic and butyric acids to be quantified using NMR. We observed an increase in SCFA production in the faecal fermentation of the three donors when L. gasseri LM19 was added compared to the control. However, as with the microbial composition, the amount of each SCFA produced was very different from one donor to another, which might be related to production by other members of the microbiota that varied between the three donors. In a previous study of consumption of a beverage prepared with $L$. gasseri CP2305, the stools of the participants also presented an increased level of SCFA, while the microbiota experienced some alterations, including an increase in the presence of bacteria from Clostridium cluster IV, known for producing higher amounts of SCFA (Sawada et al. 2016). The authors of that study could not conclude if the increase of SCFA was due to the effect of L. gasseri or due to the proliferation of bacteria that produced more SCFA. Similarly, our addition of $C$. perfringens also increased SCFA levels to greater than those seen with $L$. gasseri LM19. SCFA production also depends on diet and availability of nutrients in the gastrointestinal tract as well as the resident microbiota (den Besten et al. 2013; Holmes et al. 2017).

This work shows the ability of $L$. gasseri LM19, a multibacteriocin breast milk isolate, to survive in colon conditions. Its ability to express different bacteriocin genes, including a novel gassericin $\mathrm{M}$, under these conditions, makes it an interesting candidate for further studies.

Acknowledgements The authors would like to thank Dr. Lee Kellingray for training in the colon model system and Dr. Lizbeth Sayavedra, Dr. Maria Diaz-Garcia, Dr. Bhavika Parmanand and Saskia Neuert for training in QIIME2.

Funding information The authors are grateful for funding from Walsh Fellowship Project 2015066 (EG-G) and BBSRC Institute Strategic Programme Grant BB/R012490/1 and BBS/E/F/000PR10356 (Quadram Institute Biosciences, MJM and AN). Research in the Cotter lab is also supported by SFI; PI award "Obesibiotics" (SFI/11/PI/1137) and centre grant "APC Microbiome Institute" (SFI/12/RC/2273).

\section{Compliance with ethical standards}

Conflict of interest The authors declare that they have no conflicts of interest.

Ethical statement Faecal samples were provided by different donors, from a study approved by the QIB Human Research Governance committee (IFR01/2015) registered at http://www.clinicaltrials.gov (NCT02653001). The participants provided their written informed consent to participate in this study. 
Open Access This article is licensed under a Creative Commons Attribution 4.0 International License, which permits use, sharing, adaptation, distribution and reproduction in any medium or format, as long as you give appropriate credit to the original author(s) and the source, provide a link to the Creative Commons licence, and indicate if changes were made. The images or other third party material in this article are included in the article's Creative Commons licence, unless indicated otherwise in a credit line to the material. If material is not included in the article's Creative Commons licence and your intended use is not permitted by statutory regulation or exceeds the permitted use, you will need to obtain permission directly from the copyright holder. To view a copy of this licence, visit http://creativecommons.org/licenses/by/4.0/.

\section{References}

Abramov V, Khlebnikov V, Kosarev I, Bairamova G, Vasilenko R, Suzina N, Machulin A, Sakulin V, Kulikova N, Vasilenko N, Karlyshev A, Uversky V, Chikindas ML, Melnikov V (2014) Probiotic properties of Lactobacillus crispatus 2,029: homeostatic interaction with cervicovaginal epithelial cells and antagonistic activity to genitourinary pathogens. Probiotics Antimicrob Proteins 6:165-176. https:// doi.org/10.1007/s12602-014-9164-4

Altschul SF, Gish W, Miller W, Myers EW, Lipman DJ (1990) Basic local alignment search tool. J Mol Biol 215:403-410. https://doi.org/10. 1016/S0022-2836(05)80360-2

Bankevich A, Nurk S, Antipov D, Gurevich AA, Dvorkin M, Kulikov AS, Lesin VM, Nikolenko SI, Pham S, Prjibelski AD, Pyshkin AV, Sirotkin AV, Vyahhi N, Tesler G, Alekseyev MA, Pevzner PA (2012) SPAdes: a new genome assembly algorithm and its applications to single-cell sequencing. J Comput Biol 19:455-477. https:// doi.org/10.1089/cmb.2012.0021

Bogovic-Matijasic B, Rogelj I, Nes IF, Holo H (1998) Isolation and characterization of two bacteriocins of Lactobacillus acidophilus LF221. Appl Microbiol Biotechnol 49:606-612

Bokulich NA, Kaehler BD, Rideout JR, Dillon M, Bolyen E, Knight R, Huttley GA, Caporaso G (2018) Optimizing taxonomic classification of marker-gene amplicon sequences with QIIME 2's q2-featureclassifier plugin. Microbiome 6:90. https://doi.org/10.1186/s40168018-0470-z

Bolger AM, Lohse M, Usadel B (2014) Trimmomatic: a flexible trimmer for Illumina sequence data. Bioinformatics 30:2114-2120. https:// doi.org/10.1093/bioinformatics/btu170

Carver T, Harris SR, Berriman M, Parkhill J, McQuillan JA (2012) Artemis: an integrated platform for visualization and analysis of high-throughput sequence-based experimental data. Bioinformatics 28:464-469. https://doi.org/10.1093/bioinformatics/btr703

Collins FWJ, O'Connor PM, O’Sullivan O, Gómez-Sala B, Rea MC, Hill C, Ross RP (2017) Bacteriocin gene-trait matching across the complete Lactobacillus pan-genome. Sci Rep 7:3481. https://doi.org/10. 1038/s41598-017-03339-y

Cotter PD, Ross RP, Hill C (2013) Bacteriocins - a viable alternative to antibiotics? Nat Rev Microbiol 11:95-105. https://doi.org/10.1038/ nrmicro2937

Czárán TL, Hoekstra RF, Pagie L (2002) Chemical warfare between microbes promotes biodiversity. Proc Natl Acad Sci U S A 99: 786-790. https://doi.org/10.1073/pnas.012399899

den Besten G, van Eunen K, Groen AK, Venema K, Reijngoud D-J, Bakker BM (2013) The role of short-chain fatty acids in the interplay between diet, gut microbiota, and host energy metabolism. J Lipid Res 54:2325-2340. https://doi.org/10.1194/jlr.R036012
Field D, Cotter PD, Hill C, Ross RP (2015) Bioengineering lantibiotics for therapeutic success. Front Microbiol 6. https://doi.org/10.3389/ fmicb.2015.01363

Fujisawa T, Benno Y, Yaeshima T, Mitsuoka T (1992) Taxonomic study of the Lactobacillus acidophilus group, with recognition of Lactobacillus gallinarum sp nov and Lactobacillus johnsonii $\mathrm{sp}$ nov and synonymy of Lactobacillus acidophilus group A3 (Johnson et al 1980) with the type strain of L. amylovorus (Nakamura 1981). Int J Syst Bacteriol 42:487-491

Garcia-Gutierrez E (2019) New antimicrobials to target gut and food pathogens. $\mathrm{PhD}$ thesis, University of East Anglia

Garcia-Gutierrez E, Mayer MJ, Cotter PD, Narbad A (2018) Gut microbiota as a source of novel antimicrobials. Gut Microbes:1-21. https://doi.org/10.1080/19490976.2018.1455790

Hegarty JW, Guinane CM, Ross RP, Hill C, Cotter PD (2016) Bacteriocin production: a relatively unharnessed probiotic trait? F1000Res 5: 2587. https://doi.org/10.12688/f1000research.9615.1

Holmes AJ, Chew YV, Colakoglu F, Cliff JB, Klaassens E, Read MN, Solon-Biet SM, McMahon AC, Cogger VC, Ruohonen K, Raubenheimer D, Le Couteur DG, Simpson SJ (2017) Dietmicrobiome interactions in health are controlled by intestinal nitrogen source constraints. Cell Metab 25:140-151. https://doi.org/10. 1016/j.cmet.2016.10.021

Holo H, Nes IF (1989) High-frequency transformation, by electroporation, of Lactococcus lactis subsp. cremoris grown with glycine in osmotically stabilized media. Appl Environ Microb 55:3119-3123

Joerger MC, Klaenhammer TR (1986) Characterization and purification of helveticin $\mathrm{J}$ and evidence for a chromosomally determined bacteriocin produced by Lactobacillus helveticus 481. J Bacteriol 167: 439-446

Karska-Wysocki B, Bazo M, Smoragiewicz W (2010) Antibacterial activity of Lactobacillus acidophilus and Lactobacillus casei against methicillin-resistant Staphylococcus aureus (MRSA). Microbiol Res 165:674-686. https://doi.org/10.1016/j.micres.2009.11.008

Kasuga G, Tanaka M, Harada Y, Nagashima H, Yamato T, Wakimoto A, Arakawa K, Kawai Y, Kok J, Masuda T (2019) Homologous expression and characterization of gassericin $\mathrm{T}$ and gassericin $\mathrm{S}$, a novel class IIb bacteriocin produced by Lactobacillus gasseri LA327. Appl Environ Microb 85:e02815-e02818. https://doi.org/ 10.1128/AEM.02815-18

Kawai Y, Saito T, Toba T, Samant K, Itoh T (1994) Isolation and characterization of a highly hydrophobic new bacteriocin (gassericin a) from Lactobacillus gasseri LA39. Biosci Biotechnol Biochem 58: 1218-1221. https://doi.org/10.1271/bbb.58.1218

Kawai Y, Saitoh B, Takahashi O, Kitazawa H, Saito T, Nakajima H, Itoh $T$ (2000) Primary amino acid and DNA sequences of gassericin T, a lactacin F-family bacteriocin produced by Lactobacillus gasseri SBT2055. Biosci Biotechnol Biochem 64:2201-2208. https://doi. org/10.1271/bbb.64.2201

Kelsic ED, Zhao J, Vetsigian K, Kishony R (2015) Counteraction of antibiotic production and degradation stabilizes microbial communities. Nature 521:516-519. https://doi.org/10.1038/nature14485

Kim PI, Jung MY, Chang Y-H, Kim S, Kim S-J, Park Y-H (2007) Probiotic properties of Lactobacillus and Bifidobacterium strains isolated from porcine gastrointestinal tract. Appl Microbiol Biotechnol 74:1103-1111. https://doi.org/10.1007/s00253-0060741-7

Ladero V, Coton M, Fernández M, Buron N, Martín MC, Guichard H, Coton E, Alvarez MA (2011) Biogenic amines content in Spanish and French natural ciders: application of qPCR for quantitative detection of biogenic amine-producers. Food Microbiol 28:554-561. https://doi.org/10.1016/j.fm.2010.11.005

LeBlanc JG, Chain F, Martín R, Bermúdez-Humarán LG, Courau S, Langella P (2017) Beneficial effects on host energy metabolism of short-chain fatty acids and vitamins produced by commensal and 
probiotic bacteria. Microb Cell Factories 16:79-79. https://doi.org/ 10.1186/s12934-017-0691-Z

Lewis K (2013) Platforms for antibiotic discovery. Nat Rev Drug Discov 12:371-387. https://doi.org/10.1038/nrd3975

Li H, Durbin R (2010) Fast and accurate long-read alignment with burrows-wheeler transform. Bioinformatics 26:589-595. https:// doi.org/10.1093/bioinformatics/btp698

Li H, Handsaker B, Wysoker A, Fennell T, Ruan J, Homer N, Marth G, Abecasis G, Durbin R, Genome Project Data Processing S (2009) The sequence alignment/map format and SAMtools. Bioinformatics 25:2078-2079. https://doi.org/10.1093/bioinformatics/btp352

Majhenič AČ, Venema K, Allison GE, Matijašić BB, Rogelj I, Klaenhammer TR (2004) DNA analysis of the genes encoding acidocin LF221 A and acidocin LF221 B, two bacteriocins produced by Lactobacillus gasseri LF221. Appl Microbiol Biotechnol 63:705-714. https://doi.org/10.1007/s00253-003-1424-2

Maldonado-Barragán A, Caballero-Guerrero B, Martín V, Ruiz-Barba JL, Rodríguez JM (2016) Purification and genetic characterization of gassericin E, a novel co-culture inducible bacteriocin from Lactobacillus gasseri EV1461 isolated from the vagina of a healthy woman. BMC Microbiol 16:37. https://doi.org/10.1186/s12866016-0663-1

Mavrič A, Tompa G, Trmčić A, Rogelj I, Bogovič Matijašić B (2014) Bacteriocins of Lactobacillus gasseri $\mathrm{K} 7$ - monitoring of gassericin $\mathrm{K} 7 \mathrm{a}$ and $\mathrm{B}$ genes' expression and isolation of an active component. Process Biochem 49:1251-1259. https://doi.org/10.1016/j.procbio. 2014.04.022

Nagpal R, Ogata K, Tsuji H, Matsuda K, Takahashi T, Nomoto K, Suzuki Y, Kawashima K, Nagata S, Yamashiro Y (2015) Sensitive quantification of Clostridium perfringens in human feces by quantitative real-time PCR targeting alpha-toxin and enterotoxin genes. BMC Microbiol 15:219-219. https://doi.org/10.1186/s12866-015-0561-y

Pandey N, Malik RK, Kaushik JK, Singroha G (2013) Gassericin a: a circular bacteriocin produced by lactic acid bacteria Lactobacillus gasseri. W J Microbiol Biotechn 29:1977-1987. https://doi.org/10. 1007/s11274-013-1368-3

Parmanand BA, Kellingray L, Le Gall G, Basit AW, Fairweather-Tait S, Narbad A (2019) A decrease in iron availability to human gut microbiome reduces the growth of potentially pathogenic gut bacteria; an in vitro colonic fermentation study. J Nutr Biochem. https:// doi.org/10.1016/j.jnutbio.2019.01.010

Quinlan AR, Hall IM (2010) BEDTools: a flexible suite of utilities for comparing genomic features. Bioinformatics 26:841-842. https:// doi.org/10.1093/bioinformatics/btq033

Rodríguez JM (2014) The origin of human milk bacteria: is there a bacterial entero-mammary pathway during late pregnancy and lactation? Adv Nutr 5:779-784. https://doi.org/10.3945/an.114.007229

Sarmiento-Rubiano L-A, Berger B, Moine D, Zúñiga M, Pérez-Martínez G, Yebra MJ (2010) Characterization of a novel Lactobacillus species closely related to Lactobacillus johnsonii using a combination of molecular and comparative genomics methods. BMC Genomics 11:504. https://doi.org/10.1186/1471-2164-11-504

Sawada D, Sugawara T, Ishida Y, Aihara K, Aoki Y, Takehara I, Takano K, Fujiwara S (2016) Effect of continuous ingestion of a beverage prepared with Lactobacillus gasseri CP2305 inactivated by heat treatment on the regulation of intestinal function. Food Res Int 79: 33-39. https://doi.org/10.1016/j.foodres.2015.11.032

Seemann T (2014) Prokka: rapid prokaryotic genome annotation. Bioinformatics 30:2068-2069. https://doi.org/10.1093/ bioinformatics/btu 153

Selle K, Klaenhammer TR (2013) Genomic and phenotypic evidence for probiotic influences of Lactobacillus gasseri on human health. FEMS Microbiol Rev 37:915-935. https://doi.org/10.1111/15746976.12021

Singh A, Vishwakarma V, Singhal B (2018) Metabiotics: the functional metabolic signatures of probiotics: current state-of-art and future research priorities - metabiotics: probiotics effector molecules. Adv Biosci Biotec 04:43. https://doi.org/10.4236/ abb.2018.94012

Tahara T, Oshimura M, Umezawa C, Kanatani K (1996) Isolation, partial characterization, and mode of action of acidocin J1132, a twocomponent bacteriocin produced by Lactobacillus acidophilus JCM 1132. Appl Environ Microb 62:892-897

Tahara T, Yoshioka S, Utsumi R, Kanatani K (1997) Isolation and partial characterization of bacteriocins produced by Lactobacillus gasseri JCM 2124. FEMS Microbiol Lett 148:97-100. https://doi.org/10. 1111/j.1574-6968.1997.tb10273.x

Treven P, Turkova K, Trmčić A, Obermajer T, Rogelj I, Matijašić BB (2013) Detection and quantification of probiotic strain Lactobacillus gasseri $\mathrm{K} 7$ in faecal samples by targeting bacteriocin genes. Folia Microbiol 58:623-630. https://doi.org/10.1007/s12223-013-0252-8

Untergasser A, Cutcutach I, Koressaar T, Ye J, Faircloth B, Remm M, Rozen S (2012) Primer 3-new capabilities and interfaces. Nucleic Acids Res 40:e115. https://doi.org/10.1093/nar/gks596

van Heel AJ, de Jong A, Montalban-Lopez M, Kok J, Kuipers OP (2013) BAGEL3: automated identification of genes encoding bacteriocins and (non-)bactericidal posttranslationally modified peptides. Nucleic Acids Res 41:W448-W453. https://doi.org/ 10.1093/nar/gkt391

Weber T, Blin K, Duddela S, Krug D, Kim HU, Bruccoleri R, Lee SY, Fischbach MA, Müller R, Wohlleben W, Breitling R, Takano E, Medema MH (2015) antiSMASH 3.0 - a comprehensive resource for the genome mining of biosynthetic gene clusters. Nucleic Acids Res 43:W237-W243. https://doi.org/10.1093/nar/gkv437

Wegmann U, Klein JR, Drumm I, Kuipers OP, Henrich B (1999) Introduction of peptidase genes from Lactobacillus delbrueckii subsp. lactis into Lactococcus lactis and controlled expression. Appl Environ Microb 65:4729-4733

Yamano T, Iino H, Takada M, Blum S, Rochat F, Fukushima Y (2007) Improvement of the human intestinal flora by ingestion of the probiotic strain Lactobacillus johnsonii La1. Brit J Nutr 95:303-312. https://doi.org/10.1079/BJN20051507

Zorič Peternel M, Čanžek Majhenič A, Holo H, Nes IF, Salehian Z, Berlec A, Rogelj I (2010) Wide-inhibitory spectra bacteriocins produced by Lactobacillus gasseri K7. Probiotics Antimicrob Proteins 2:233-240. https://doi.org/10.1007/s12602-010-9044-5

Publisher's note Springer Nature remains neutral with regard to jurisdictional claims in published maps and institutional affiliations. 